Prepared in cooperation with the National Park Service

\title{
Spatial Variation in Fish-Tissue Mercury Concentrations in the St. Croix River Basin, Minnesota and Wisconsin, 2004
}

Scientific Investigations Report 2006-5063 



\section{Spatial Variation in Fish-Tissue Mercury Concentrations in the St. Croix River Basin, Minnesota and Wisconsin, 2004}

By Victoria G. Christensen, Stephen P. Wente, Mark B. Sandheinrich, and Mark E. Brigham

Prepared in cooperation with the National Park Service

Scientific Investigations Report 2006-5063 


\section{U.S. Department of the Interior \\ P. Lynn Scarlett, Acting Secretary}

\section{U.S. Geological Survey \\ P. Patrick Leahy, Acting Director}

\section{U.S. Geological Survey, Reston, Virginia: 2006}

For product and ordering information:

World Wide Web: http://www.usgs.gov/pubprod

Telephone: 1-888-ASK-USGS

For more information on the USGS--the Federal source for science about the Earth, its natural and living resources, natural hazards, and the environment:

World Wide Web: http://www.usgs.gov

Telephone: 1-888-ASK-USGS

Any use of trade, product, or firm names is for descriptive purposes only and does not imply endorsement by the U.S. Government.

Although this report is in the public domain, permission must be secured from the individual copyright owners to reproduce any copyrighted materials contained within this report.

Suggested citation:

Christensen, V.G., Wente, S.P., Sandheinrich, M.B., and Brigham, M.E., 2006, Spatial variation in fish-tissue mercury concentrations in the St. Croix River Basin, Minnesota and Wisconsin, 2004: U.S. Geological Survey Scientific Investigations Report 2006-5063, 26 p.

Prepared by the U.S. Geological Survey, Mounds View, Minnesota (http://mn.water.usgs.gov) 


\section{Contents}

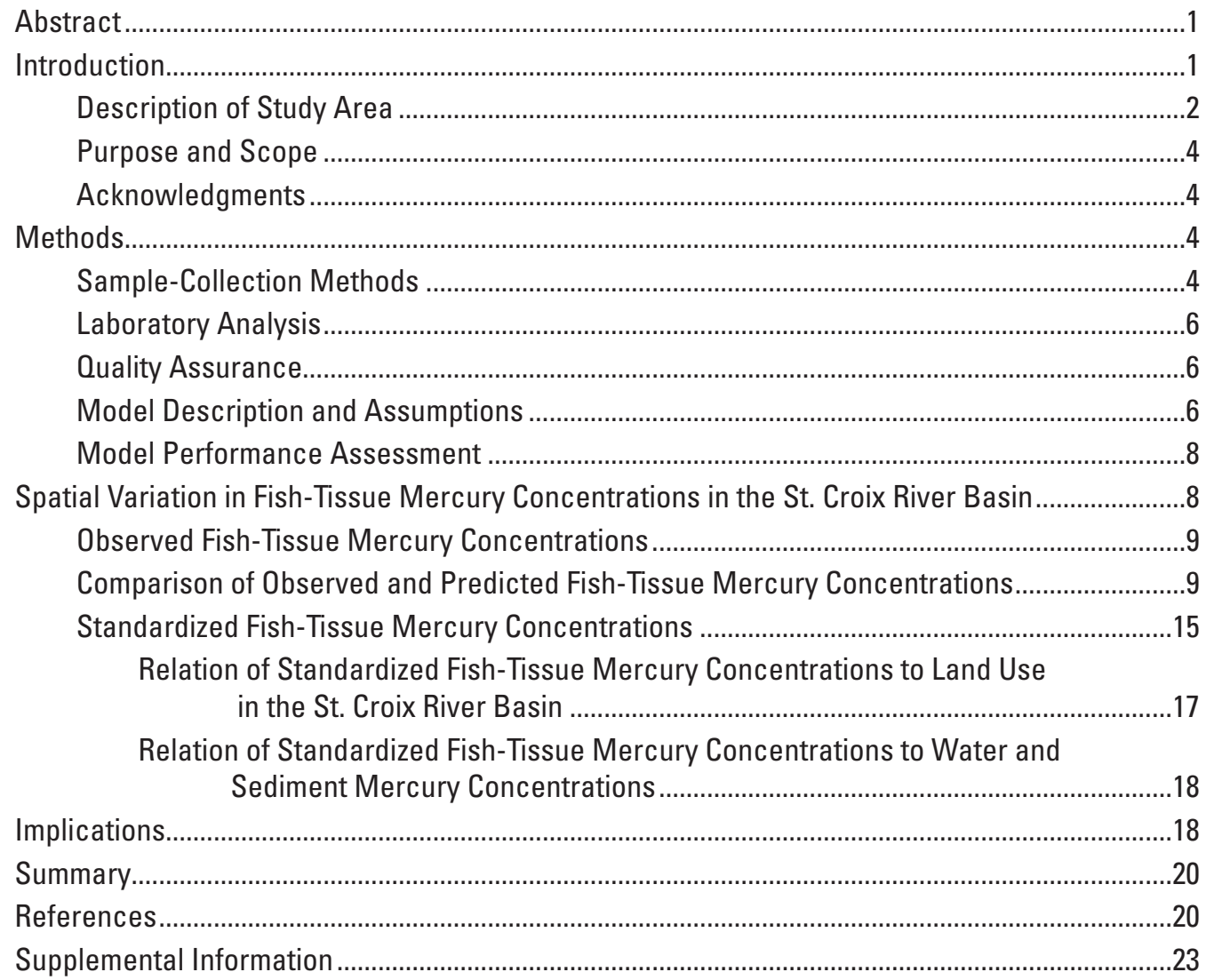

\section{Figures}

1. Map showing location of the St. Croix River Basin, Minnesota and Wisconsin, and sites where fish-tissue samples were collected during 2004.

2. Boxplots showing distribution of observed fish-tissue mercury concentrations for fish collected from the St. Croix River and tributary streams, 2004 ...........................10

3. Graphs showing comparison of observed to predicted fish-tissue mercury concentrations for the species and cuts of fish across the range of each species' fish length measured for the site

4. Boxplots showing distribution of standardized fish-tissue mercury concentrations for fish collected from the St. Croix River and tributary streams, 2004.

5. Graph and map showing comparison of standardized fish-tissue mercury concentrations from four sites sampled in the St. Croix River Basin, 2004 


\section{Tables}

1. Sampling sites, drainage area, land-use type, and sampling date, St. Croix River Basin, Minnesota and Wisconsin, 2004

2. Summary results of quality-assurance analyses by River Studies Center, University of Wisconsin, LaCrosse, during determination of total mercury in composite samples of fish from the St. Croix River Basin, Minnesota and Wisconsin, 2004

3. Results for total mercury reference materials from the U.S. National Institute of Standards and Technology and the National Research Council of Canada analyzed by the River Studies Center, University of Wisconsin, LaCrosse

4. Comparison of model fit and prediction error across a wide range of observed fish-tissue mercury concentrations at each of the 14 sites sampled in the St. Croix River Basin, Minnesota and Wisconsin, 2004

5. Fish-tissue mercury concentrations exceeding U.S. Environmental Protection Agency's human-health criterion in the St. Croix River Basin, Minnesota and Wisconsin, 2004

6. Comparison of standardized fish-tissue mercury, total mercury and methylmercury in water, and total mercury in sediment at selected sites in the St. Croix River Basin, Minnesota and Wisconsin, 2000-01 and 2004

7. Sites where species occurred and number of fish-tissue mercury samples in the National Fish-Tissue Mercury Data Set for all species captured at the 14 St. Croix River Basin sites studied, Minnesota and Wisconsin, 2004 


\section{Conversion Factors, Abbreviations, and Datum}

\begin{tabular}{|c|c|c|}
\hline Multiply & By & To obtain \\
\hline \multicolumn{3}{|c|}{ Length } \\
\hline centimeter $(\mathrm{cm})$ & 0.3937 & inch (in.) \\
\hline inch (in.) & 2.54 & centimeter $(\mathrm{cm})$ \\
\hline kilometer (km) & 0.6214 & mile (mi) \\
\hline millimeter $(\mathrm{mm})$ & 0.03937 & inch (in.) \\
\hline \multicolumn{3}{|c|}{ Area } \\
\hline square kilometer $\left(\mathrm{km}^{2}\right)$ & 247.1 & acre \\
\hline square kilometer $\left(\mathrm{km}^{2}\right)$ & 0.3861 & square mile $\left(\mathrm{mi}^{2}\right)$ \\
\hline \multicolumn{3}{|c|}{ Mass } \\
\hline $\operatorname{gram}(\mathrm{g})$ & 0.03527 & ounce, avoirdupois (oz) \\
\hline kilogram (kg) & 2.205 & pound avoirdupois (lb) \\
\hline \multicolumn{3}{|c|}{ Hydraulic gradient } \\
\hline meter per kilometer $(\mathrm{m} / \mathrm{km})$ & 5.28 & foot per mile ( $\mathrm{ft} / \mathrm{mi})$ \\
\hline
\end{tabular}

Temperature in degrees Celsius $\left({ }^{\circ} \mathrm{C}\right)$ may be converted to degrees Fahrenheit $\left({ }^{\circ} \mathrm{F}\right)$ as follows:

$$
{ }^{\circ} \mathrm{F}=\left(1.8 x^{\circ} \mathrm{C}\right)+32
$$

Temperature in degrees Fahrenheit $\left({ }^{\circ} \mathrm{F}\right)$ may be converted to degrees Celsius $\left({ }^{\circ} \mathrm{C}\right)$ as follows:

$$
{ }^{\circ} \mathrm{C}=\left({ }^{\circ} \mathrm{F}-32\right) / 1.8
$$

Horizontal coordinate information is referenced to the North American Datum of 1983 (NAD 83).

Concentrations of chemical constituents in fish tissue are given in micrograms per kilogram $(\mu \mathrm{g} / \mathrm{kg})$.

Concentrations of chemical constituents in water are given in nanograms per liter ( $\mathrm{ng} / \mathrm{L})$.

Concentrations of chemical constituents in sediment are given in micrograms per gram $(\mu \mathrm{g} / \mathrm{g})$.

NOTE TO USERS: Use of hectare (ha) as an alternative name for square hectometer $\left(\mathrm{hm}^{2}\right)$ is restricted to the measurement of small land or water areas. 


\title{
Spatial Variation in Fish-Tissue Mercury Concentrations in the St. Croix River Basin, Minnesota and Wisconsin, 2004
}

\author{
By Victoria G. Christensen', Stephen P. Wente ${ }^{2}$, Mark B. Sandheinrich ${ }^{3}$, and Mark E. Brigham ${ }^{1}$
}

\section{Abstract}

Parts of the St. Croix River in Minnesota and Wisconsin are under fish-consumption advisories because of elevated mercury concentrations that have been measured in fish from this river. The U.S. Geological Survey, National Park Service, and the University of Wisconsin, LaCrosse, cooperated in a study to determine the spatial variation of mercury in fish in the St. Croix River and selected tributaries.

Game and nongame fish were collected at 14 sites during summer 2004 and identified to species. One hundred ninetythree (193) composite tissue samples were analyzed for total mercury as whole fish, skin-on fillet, or skin-off fillet. A model of mercury in fish was used to standardize fish-tissue mercury concentrations to a common species, tissues sampled, and length of fish allowing for more consistent comparisons among sites.

Rush Creek near Rush City, Minnesota, was identified as having high median standardized fish-tissue mercury concentrations compared to other tributaries sampled. Previous studies identified Rush Creek as having high concentrations of methylmercury in water and high concentrations of total mercury in sediment when compared to other sites in the St. Croix River Basin.

Sites in the St. Croix River Basin that drained forest/wetland watersheds had significantly higher median fish-tissue mercury concentrations than sites draining agricultural/forested watersheds $(\mathrm{p}=0.0003)$. There also was a significant relation between fish-tissue mercury concentration and methylmercury concentration in water ( $r h o=0.580$, $\mathrm{p}=0.02$ ) and between fish-tissue mercury and total mercury in sediment ( $\mathrm{rho}=0.569, \mathrm{p}=0.03)$. Observed fish-tissue mercury concentrations exceeding the U.S. Environmental Protection Agency's (USEPA) human-health criterion of 300 micrograms per kilogram occurred at 7 of the 14 sampling sites. The model

\footnotetext{
${ }^{1}$ U.S. Geological Survey, Mounds View, Minnesota.

${ }^{2}$ U.S. Geological Survey, Reston, Virginia.

${ }^{3}$ River Studies Center, University of Wisconsin, LaCrosse, Wisconsin.
}

predicted concentrations exceeding USEPA's criterion at all of the seven sites where exceedances were observed and four of the seven sites where exceedances were not observed. The implication is that fish-consumption advisories that are based on observed concentrations (of a subset of the species that occur at the site or smaller fish) could underestimate the threat to human health.

Using the model to predict fish-tissue mercury concentrations allows site-specific fish-consumption advisories to be developed for multiple species and different lengths of fish. Potential mercury exposure to fish consumers may be reduced because an individual can choose to consume sizes and species of fish that are expected to have lower fish-tissue mercury concentrations. The National Park Service can use these results to more reliably monitor fish-tissue mercury concentrations in the St. Croix River Basin and better assess potential health effects of fish consumption to humans and wildlife.

\section{Introduction}

Mercury has become a concern in many lakes and rivers in the United States because of potential toxicity (Wetzel, 2001, p. 309) and because of concentrations elevated above fish consumption advisory levels (Wiener and others, 2002, p. 4). Most mercury enters aquatic systems via atmospheric transport and deposition as inorganic mercury (Bloom and Watras, 1989). Mercury is a naturally occurring chemical element. Although some mercury has always cycled between terrestrial, atmospheric, and aquatic environments, human activities have greatly increased the movement of mercury, resulting in greater mercury loads to aquatic ecosystems. Sources of human-mobilized atmospheric mercury include coal combustion, waste incineration, metal-ore smelting, the chlor-alkali industry, and other sources (Hem, 1992, p. 142; Schroeder and Munthe, 1998; Wiener and others, 2002).

Bacterial methylation of inorganic mercury produces methylmercury (Compeau and Bartha, 1985; Gilmour and others, 1998), which is the most toxic, bioaccumulative natural form of mercury. Methylmercury is ubiquitous in aquatic 
ecosystems. Methylmercury biomagnifies in aquatic food webs (Watras and Bloom, 1992; Morel and others, 1998), potentially reaching concentrations sufficient to induce sublethal, toxic effects in piscivorous (fish-consuming) fish (Friedmann and others, 1996), wildlife (Barr, 1986; Meyer and others, 1998), and humans who routinely consume fish with high mercury concentrations (Shubat and others, 1995).

Water quality generally is considered to be good in the upper St. Croix and Namekagon Rivers (fig. 1). However, mercury contamination has been identified as a serious aquatic resource concern in the St. Croix River Basin and in the St. Croix National Scenic Riverway (Holmberg and others, 1997). On the basis of observed fish-tissue mercury concentrations in fish taken from the St. Croix River (a popular fishing destination), the States of Minnesota and Wisconsin have issued fishconsumption advisories for portions of the river (Minnesota Department of Health, 2000; Wisconsin Division of Health, 2000). Although it is not uncommon for water bodies in this area to have mercury concentrations sufficient to invoke fishconsumption advisories, this river, along with the Namekagon River that drains into it, make up the St. Croix National Scenic Riverway. The National Park Service (NPS) is charged to preserve and protect the riverway. NPS has supported research throughout the St. Croix River Basin in an effort to determine if the sources of the mercury can be controlled or managed.

Concern over mercury and methylmercury levels in the St. Croix National Scenic Riverway prompted a reconnaissance study (Payne and Hansen, 2003) and a study of streambed sediments (Brigham, 2002). In the reconnaissance study, 16 tributary sites in the St. Croix River Basin were assessed by sampling the water at each site for total mercury, methylmercury, total organic carbon, and physical properties. Sites were selected because drainage areas were fairly similar in size, and there was a large difference in land use and land cover among the tributary basins. An initial round of sampling from this reconnaissance study found a significant correlation between methylmercury and basin characteristics such as forested and wetland land cover. This finding was not unexpected given literature observations that inorganic mercury is efficiently methylated in wetlands. Furthermore, Hurley and others (1995) reported a correlation between instantaneous methylmercury yields and percentage of the basin that is covered with wetlands. Brigham (2002) analyzed streambed sediments from 30 sites in the St. Croix River Basin and found elevated concentrations of mercury (above human-health criteria) in Rush Creek downstream from Rush City, Minnesota.

Interpretation of fish-tissue mercury data sets can be complicated. It is difficult to collect samples with consistent sample characteristics (same species, tissues sampled, and length), especially if samples are collected over large regions (a single species may not occur over the entire region) or a variety of habitats. In addition, fish-tissue mercury concentrations vary with sample characteristics. Among species, fishtissue mercury concentrations tend to increase with trophic level (MacCrimmon and others, 1983; Suns and others, 1987; Cope and others, 1990; Kim and Burggraaf, 1999). Within species, fish-tissue mercury concentrations typically vary with length of fish (and other measures of fish size or age) (MacCrimmon and others, 1983). Within individual fish, different tissues may have different mercury concentrations (Giblin and Massaro, 1973; Boudou and Ribeyre, 1983; Harrison and others, 1990). Therefore, different cuts of the same fish (whole fish, skin-on fillet, or skin-off fillet) are expected to have different fish-tissue mercury concentrations.

Because of the growing concern over fish-tissue mercury in the St. Croix River Basin, the U.S. Geological Survey (USGS), NPS, and the University of Wisconsin, LaCrosse, cooperatively examined the distribution of fish-tissue mercury concentrations at multiple sites within the St. Croix River Basin. With this information, NPS may better determine the sources of mercury to fish and the mercury concentrations in fish consumed by humans (typically fillet samples of game fish) as well as those consumed by wildlife (typically wholefish samples from both game and nongame fish). The results of this study also may help the Minnesota Department of Health and the Wisconsin Division of Health in their decisions regarding fish-consumption advisories.

\section{Description of Study Area}

The St. Croix National Scenic Riverway, which includes the Namekagon River, was established in 1968 under the Wild and Scenic Rivers Act. The portion of the river south of St. Croix Falls, Wisconsin, was added to the system in 1972 as the Lower St. Croix National Scenic Riverway. The St. Croix River originates near Solon Springs, Wisconsin, and flows approximately $248 \mathrm{~km}$ southward where it joins the Mississippi River at Prescott, Wisconsin. The upstream $40 \mathrm{~km}$ of the St. Croix River are solely within Wisconsin, whereas the remaining reaches of the river form the boundary between Minnesota and Wisconsin. The Namekagon River originates at Lake Namekagon and flows $157 \mathrm{~km}$, entirely in Wisconsin, to its confluence with the St. Croix River. The St. Croix River Basin drains $20,100 \mathrm{~km}^{2}$ (fig. 1). More than 15 major tributaries in Minnesota and Wisconsin feed into the St. Croix-Namekagon complex. NPS manages a corridor along both rivers roughly 0.4 to $0.8 \mathrm{~km}$ wide and also has made extensive use of scenic easements for properties near the rivers that remain in private ownership.

Land use and land cover in the St. Croix River Basin is predominantly forest and wetlands in the upper St. Croix River Basin, progressing to more agricultural land in the lower St. Croix River Basin (Payne and others, 2002). There are several dams in the St. Croix River Basin, which serve as barriers to fish migration. The river generally has a low gradient throughout its course (Fago and Hatch, 1993). The main stem upstream from the dam at St. Croix Falls, Wisconsin, has a steeper slope $(0.27 \mathrm{~m} / \mathrm{km})$ than downstream from the dam $(0.095 \mathrm{~m} / \mathrm{km})$ (Montz and others, 1989).

The bedrock in the St. Croix River Basin is covered by glacial deposits. Wadena Lobe sediments overlie the western 


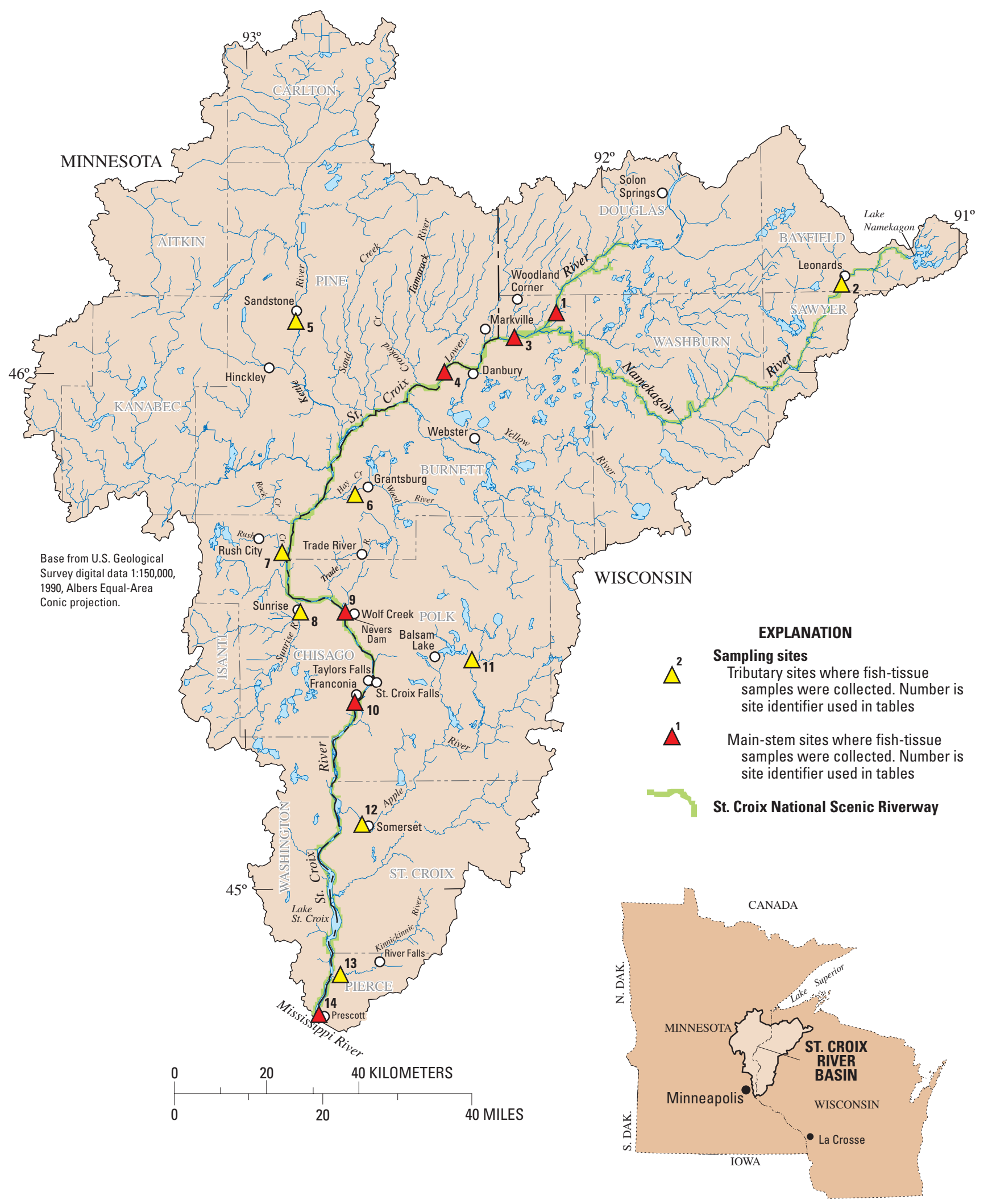

Figure 1. Location of the St. Croix River Basin, Minnesota and Wisconsin, and sites where fish-tissue samples were collected during 2004. 
Spatial Variation in Fish-Tissue Mercury Concentrations in the St. Croix River Basin, Minnesota and Wisconsin, 2004

part of the basin (Ojakangas and Matsch, 1982), and noncalcareous Superior Lobe sediments overlie much of the remainder of the basin. An examination of sediments in the headwaters of the St. Croix Basin (Cannon and Woodruff, 2003) show that the A-horizon soils (topsoil) have greater mercury concentrations than the C-horizon soils (those that overlie bedrock).

The St. Croix River Basin is a biologically diverse environment, with 110 fish species (Fago and Hatch, 1993). Ten species are classified as threatened or endangered species by the State of Minnesota or Wisconsin (Anderson and Varro, 2002).

\section{Purpose and Scope}

The purpose of this report is to describe spatial variation in fish-tissue mercury concentrations in the St. Croix River Basin on the basis of fish-tissue data collected during the summer of 2004. Specific objectives of this report are to:

1. Describe a fish-tissue mercury statistical model for the St. Croix River Basin that allows fish-tissue mercury concentrations to be compared among sites without the confounding effect of variation in sample characteristics (species, cut, and length of the fish).

2. Identify sites where concentrations of mercury in fish tissue are high relative to other sites in the basin.

3. Compare fish-tissue mercury concentrations to landcover characteristics that may affect mercury loading, speciation, and bioaccumulation in the St. Croix River Basin.

4. Compare fish-tissue mercury concentrations to historical water-column concentrations of methylmercury and total mercury (Payne and Hansen, 2003) and sediment mercury concentrations (Brigham, 2002).

\section{Acknowledgments}

Jack Enblom, Nick Proulx, and Konrad Schmidt of the Minnesota Department of Natural Resources and Frank Pratt and Marty Engel of the Wisconsin Department of Natural Resources provided expertise in fish collection and taxonomic identification. Irina Comardicea, Landon Gryczkowski, Jacque Hamilton, Luke Thompson, and Christine Yaeger of USGS and Jayna DeVore and Tyler Pavlowich of the Minnesota Department of Natural Resources aided in the collection and measurement of the fish samples. Sean Bailey, Matt Brantner, and Pete Liska of the River Studies Center performed fishsample preparation and total mercury determinations. Bill Brumbaugh (USGS Columbia Environmental Research Center), Jim Stark, Bob Borgstede, and Lanna Combs (USGS), and Jay Glase (NPS) provided valuable input into preparation of this report. Randy Ferrin (NPS) provided project guidance. NPS provided funding for this study.

\section{Methods}

Samples generally were collected at 14 sites (table 1, fig. 1) where water samples were investigated for mercury and methylmercury in a previous U.S. Geological Survey study (Payne and Hansen, 2003). These sites were selected to represent a variety of land use and land cover. The 14 sites included 8 tributary sites and 6 main-stem St. Croix River sites. The co-location of sampling sites provided a consistency of data and a more complete data set on mercury cycling in the St. Croix River Basin. In addition, a recent (summer 2004) USGS National Water-Quality Assessment Program (NAWQA) mercury synoptic study was conducted at many of these same sites. The NAWQA study included mercury in water and sediment. The results from the NAWQA study are compared to the fish-tissue mercury concentrations presented in this report.

\section{Sample-Collection Methods}

Fish sampling was conducted during July through September 2004. A total of 193 composite fish samples were collected. Between 11 and 14 composite fish samples were analyzed from each of the 14 sites. Sample characteristics were selected to maximize comparability to a national data set (http://emmma.usgs.gov) and to allow for prediction of fishtissue mercury concentrations for as many species encountered at these sites as possible. Comparability to the national data set was improved by selecting species and cuts of fish that already occur in the national data set (mostly game fish). Many of the species that occurred at the St. Croix River Basin sites were nongame fish. Reserving some of the fish samples from each site for sampling species not presently in the national data set allowed development of a statistical model to predict fishtissue mercury concentrations for many of these additional species. Because these species may occur in the diet of fishconsuming wildlife, sampling these species may be useful for understanding effects on wildlife populations.

Fish were collected at each of the sites using pulsed, direct-current electrofishing equipment during late-summer low-flow conditions. All fish captured at each site were identified to species with the exception of some young-of-the-year fish and small lampreys. Maximum and minimum fish lengths were measured for all fish species identified (henceforth, fish length is provided in inches because this unit is familiar among U.S. fish consumers and often is used in fish-consumption advisories). State-listed threatened and endangered species were released immediately following capture with minimal harm.

Fish to be retained for mercury analysis were placed in plastic bags with water obtained from the sampling site and transported on ice to the USGS office in Mounds View, Minnesota. The sample bags (with water) were transferred to refrigerators until fish were measured and weighed. Many of the fish collected were small (many less than 3 in.) and would be difficult to accurately weigh in the field. Therefore, 


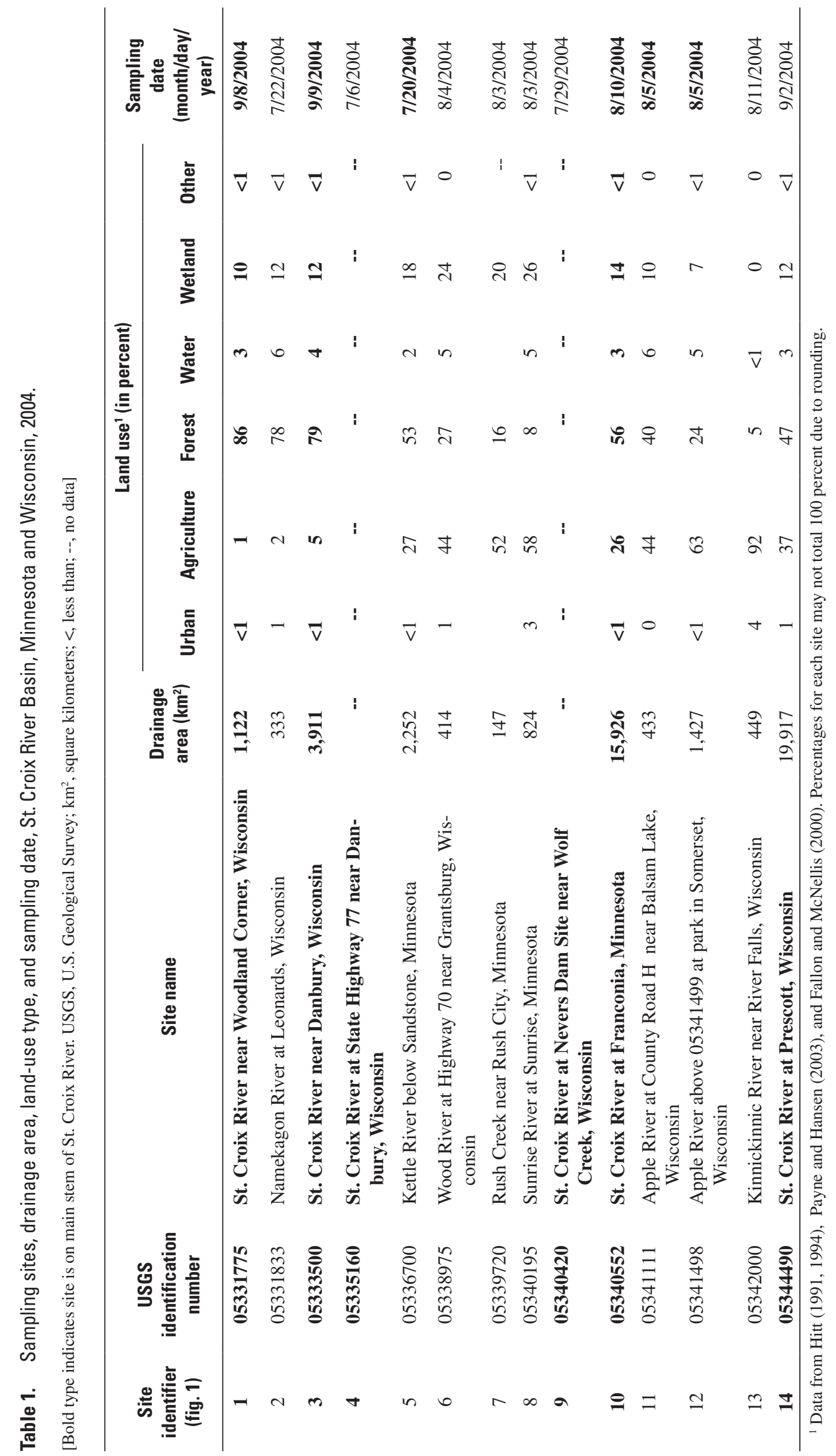


collected fish were kept in site water to allow more accurate measurement of fish wet weights in a controlled laboratory setting. After length and weight were measured, fish were kept frozen until analysis.

\section{Laboratory Analysis}

Fish samples were analyzed for total mercury by the River Studies Center, University of Wisconsin, La Crosse, Wisconsin, under the direction of Dr. Mark B. Sandheinrich. For whole-fish composite samples, composed of 1 to 5 fish, frozen carcasses were freeze dried at less than or equal to $-85{ }^{\circ} \mathrm{C}$ in food-grade plastic bags to a constant dry weight. For skin-on or skin-off fillet composite samples, frozen carcasses of fish were first defrosted, dissected, and a sample of axial muscle (skin-off fillet or skin-on fillet) was freeze dried at less than or equal to $-85^{\circ} \mathrm{C}$ in a food-grade plastic bag to a constant dry weight. Dried tissue was homogenized with a stainless-steel food blender, and a subsample of tissue from each fish comprising the composite sample was weighed, combined, homogenized, and stored in a food-grade plastic bag. Subsamples $(0.10 \mathrm{~g})$ of composite samples were digested following a modification of U.S. Environmental Protection Agency (USEPA) method 1631 (U.S. Environmental Protection Agency, 2002). Subsamples were digested for 3 hours at 90 to $95{ }^{\circ} \mathrm{C}$ in a solution of sulfuric acid $\left(\mathrm{H}_{2} \mathrm{SO}_{4}\right)$ and nitric acid $\left(\mathrm{HNO}_{3}\right.$ ) followed by digestion with bromine chloride $(\mathrm{BrCl})$ for 8 hours at $40^{\circ} \mathrm{C}$. Each digested subsample was analyzed by flow-injection, cold-vapor atomic fluorescence spectroscopy.

\section{Quality Assurance}

Accuracy and precision of mercury determinations analyzed by the River Studies Center for each batch of composite fish samples was assessed by the concomitant analysis of (1) certified reference materials from the National Research Council of Canada (NRCC) and the U.S. National Institute of Standards and Technology (NIST), (2) spiked (before digestion) subsamples of homogenized fish, (3) triplicate subsamples of homogenized fish, and (4) blank and standard samples taken through digestion procedures. The River Studies Center's quality-assurance results for determinations of total mercury in composite samples are summarized in tables 2 and 3.

Twenty sample homogenates also were analyzed at the Trace Element Research Laboratory (TERL) at Texas A\&M University (College Station, Texas), a USGS-approved laboratory for fish-tissue mercury analysis, to provide assurance that the River Studies Center laboratory produced accurate concentration values. Freeze-dried homogenates were selected to span the entire range of concentrations measured by the River Studies Center laboratory. The resulting difference in mercury content using the raw data from both laboratories was comparatively small; the mean relative percentage difference was 6.48. However, TERL determined small but non-zero moisture in all samples (range 2.79-7.21 percent). It is likely that the dried homogenates acquired this moisture after the initial measurement by the River Studies Center. When a correction was applied for the moisture in the samples at TERL, the fish-tissue mercury concentrations determined by TERL and River Studies Center differed by a mean relative percentage of 1.18, indicating good agreement between the two laboratories. Among individual samples, the largest percentage differences occurred for samples with the lowest fish-tissue mercury concentrations.

\section{Model Description and Assumptions}

A national descriptive statistical model of mercury in fish (NDMMF) was developed by USGS in cooperation with the National Institute of Environmental Health Sciences (NIEHS) to partition variation in fish-tissue mercury concentrations between the effects of spatiotemporal and sample characteristic (species, cut, and length of fish) variation (Wente, 2004). Data from the St. Croix River Basin were appended to the national fish-tissue mercury data set (http://emmma.usgs.gov), and the model was recalibrated for this report.

NDMMF is a statistical model related to analysis of covariance and multiple-linear regression. The model is similar to the equation for a line:

$$
\log _{e}\left(C_{i j k}+1\right)=\alpha_{k} \times \log _{e}\left(\text { length }_{i j k}+1\right)+\beta_{j}+\varepsilon_{i j k},
$$

where

$$
\begin{aligned}
& \alpha_{k} \text { and } \beta_{j} \quad \text { are the slope and intercept, respectively, of } \\
& \text { the linear relation between the } \log _{e}\left(C_{i j k}+\right. \\
& \text { 1) and } \log _{e}\left(\text { length }_{i j k}+1\right) \text { terms; } \\
& C_{i j k} \quad \text { is the fish-tissue mercury concentration } \\
& \text { in micrograms of mercury per kilogram } \\
& \text { of fish tissue from the } i^{\text {th }} \text { sample of the } j^{\text {th }} \\
& \text { sampling event (the term 'sampling event' } \\
& \text { refers to a collection of samples from a } \\
& \text { specific site and date) for the } k^{\text {th }} \text { species } \\
& \text { and cut combination; } \\
& \alpha_{k} \quad \text { is a set of parameters relating variation } \\
& \text { in fish-tissue mercury concentration to } \\
& \text { fish length for each of } m \text { species and cut } \\
& \text { combinations of fish; } \\
& \text { length }_{i j k} \quad \text { is the length of the } i^{\text {th }} \text { sample of the } j^{\text {th }} \\
& \text { sampling event for the } k^{\text {th }} \text { species (fish } \\
& \text { length is used in this model as the measure } \\
& \text { of fish size because length data commonly } \\
& \text { are available for fish-tissue mercury } \\
& \text { results); } \\
& \beta_{j} \quad \text { is a set of parameters describing variation } \\
& \text { in fish-tissue mercury concentrations } \\
& \text { among each of } \mathrm{n} \text { sampling events; and } \\
& \varepsilon_{i j k} \quad \text { is an error term for the } i^{\text {th }} \text { sample of the } j^{\text {th }} \\
& \text { sampling event for the } k^{\text {th }} \text { species. }
\end{aligned}
$$


Table 2. Summary results of quality-assurance analyses by River Studies Center, University of Wisconsin, LaCrosse, during determination of total mercury in composite samples of fish from the St. Croix River Basin, Minnesota and Wisconsin, 2004.

[NIST, U.S. National Institute of Standards and Technology; $\mu \mathrm{g} / \mathrm{kg}$, micrograms per kilogram]

\begin{tabular}{|c|c|c|c|}
\hline Material analyzed & $\begin{array}{l}\text { Number of } \\
\text { samples }\end{array}$ & Performance measure & Results \\
\hline $\begin{array}{l}\text { Standard reference } \\
\text { materials }\end{array}$ & 35 & $\begin{array}{l}\text { Measured concentrations within the } \\
\text { certified range }\end{array}$ & 25 of 35 samples \\
\hline NIST & 12 & $\begin{array}{l}\text { Method detection limit } \\
\quad(\mu \mathrm{g} / \mathrm{kg} \text { dry weight })\end{array}$ & $1.88 \mu \mathrm{g} / \mathrm{kg}$ \\
\hline $\begin{array}{l}\text { Fish tissue spiked before } \\
\text { digestion }\end{array}$ & 60 & $\begin{array}{l}\text { Percent recovery } \\
\text { Mean } \\
\text { Range }\end{array}$ & $\begin{array}{l}96.5 \text { percent } \\
84.1-112.1 \text { percent }\end{array}$ \\
\hline $\begin{array}{l}\text { Triplicate subsamples of } \\
\text { fish }\end{array}$ & 60 & $\begin{array}{l}\text { Method precision (coefficient of varia- } \\
\text { tion) } \\
\text { Mean } \\
\text { Range }\end{array}$ & $\begin{array}{l}4.5 \text { percent } \\
0.4-8.3 \text { percent }\end{array}$ \\
\hline
\end{tabular}

Table 3. Results for total mercury reference materials from the U.S. National Institute of Standards and Technology (NIST) and the National Research Council of Canada (NRCC) analyzed by the River Studies Center, University of Wisconsin, LaCrosse.

[ $\mu \mathrm{g} / \mathrm{kg}$; micrograms per kilogram; NIST, U.S. National Institute of Standards and Technology; NRCC, National Research Council of Canada]

\begin{tabular}{lcccc}
\hline Reference material & $\begin{array}{c}\text { Certified concentration } \\
\text { range } \\
(\boldsymbol{\mu} \mathbf{g} / \mathbf{k g} \text { dry weight) }\end{array}$ & $\begin{array}{c}\text { Number of } \\
\text { samples }\end{array}$ & $\begin{array}{c}\text { Mean concentration } \\
\text { ( } \boldsymbol{\mu g} / \mathbf{k g ~ d r y ~ w e i g h t )}\end{array}$ & $\begin{array}{c}\text { 95-percent confidence } \\
\text { interval } \\
\text { ( } \boldsymbol{\mu g} / \mathbf{k g} \mathbf{~ d r y ~ w e i g h t )}\end{array}$ \\
\hline $\begin{array}{l}\text { NIST mussel tissue } \\
\text { NRCC lobster hepato- } \\
\text { pancreas }\end{array}$ & $57.4-64.6$ & 12 & 60.5 & $57.5-64.1$ \\
NRCC dogfish muscle & $210-330$ & 12 & 258 & $242-274$ \\
\hline
\end{tabular}


Because $\alpha_{k}$ and $\beta_{j}$ can take on $m$ and $n$ values, respectively, equation 1 describes multiple $(m \times n)$ lines in log-log space or, after back transformation into arithmetic space, a series of curves. However, the actual model can be quite complex because the number of species, $m$, and number of sampling events, $n$, can be very large. The model was calibrated to the national fish-tissue mercury data set of 48,025 fish-tissue mercury concentration measurements. Because the data set contains left-censored (below detection level) values, the model is implemented in SAS code (SAS Institute, Inc., 1989) using a SAS procedure (LIFEREG) that can produce unbiased parameter estimates from data sets with censored observations. A more thorough discussion and evaluation of this model is available in Wente (2004).

A major difference between the modeling methods described in Wente (2004) and the modeling methods used in the analysis described in this report is the use of a statistical procedure to weight observations of the fish-mercury concentration on the basis of the number of fish included in each composite sample. Sampling theory would predict that composite samples containing larger numbers of individuals should provide more accurate estimates of the mean response than samples composed of a few individuals. Therefore, statistical weights were assigned to each fish-tissue mercury observation in the St. Croix data set so that samples of individual fish receive a statistical weight of 1 , whereas composite samples receive statistical weights equal to the number of fish in the composite. Because the national fish-tissue mercury data set does not indicate the number of fish included in a sample for all observations, statistical weights were assigned on the basis of the number of fish in the sample where indicated and assumed to be 1 (an individual fish sample) where not indicated.

\section{Model Performance Assessment}

The model's performance was assessed by measuring the fit of the model's predictions to the observed concentrations from each site as well as across the entire St. Croix data set. Because NDMMF performs a weighted regression analysis, the same statistical weighting scheme was used in assessing the model fit.

The first measure of model fit is a weighted coefficient of determination $\left(R^{2}\right)$ that is based on the log-transformed observations:

$$
R^{2}=1-\frac{S S E}{C S S},
$$

where SSE is the weighted sum of squared errors for the log of fish-tissue mercury concentration observations (the sum of the product of each observation's squared residual times its weight), and CSS is the weighted sum of squares of the log of fish-tissue mercury concentration observations corrected for the mean of the log fish-tissue mercury concentration observations (the sum of the product of each observation's squared deviation from the mean fish-tissue mercury concentration times its statistical weight) [the log of fish-tissue mercury concentrations is calculated as $\left.\log _{e}(\mu \mathrm{g} \mathrm{Hg} / \mathrm{kg}+1)\right]$. This measure of model fit can be interpreted as the proportion of variation explained by the model in terms of the response variable units as submitted to the model (log-transformed fish-tissue mercury concentrations). This measure is useful in this report for comparing variation in the fit of the model to the observed fish-tissue mercury concentrations from different sites.

Another measure of model fit is a weighted root mean square error $\left(R M S E_{W}\right)$, which is transformed into a measure of prediction error $(P E)$ and expressed as a percentage. The $R M S E_{W}$ is calculated as:

$$
\operatorname{RMSE}_{W}=\sqrt{\frac{n \times S S E}{(n-p) \times \sum_{i=1}^{n} w_{i}}},
$$

where $n$ is the number of observations; $p$ is the number of parameters estimated; and $w_{i}$ is the statistical weight (number of fish in the composite sample) for the $i^{\text {th }}$ sample. PE is calculated as (Schwartz and others, 2006):

$$
P E=100 \times\left(e^{\left(R M S E_{W}-\frac{R M S E_{W}^{2}}{2}\right)}-1\right) .
$$

PE describes the dispersion of error around the predicted values. Because the dispersion of error for a log-linear model varies directly with predicted value, it is natural to express this dispersion as a percentage of the predicted value. The interpretation of PE is the percentage of the predicted value (plus and minus) within which the region bounded by +1 and -1 standard deviations falls. This region encompasses approximately 66 percent of the observations. Therefore, if the PE is 35 percent, then 66 percent of the observed fish-tissue mercury concentrations will fall within 35 percent of the predicted fish-tissue mercury concentrations. Lower PE values indicate less error dispersion and, therefore, a better model fit.

\section{Spatial Variation in Fish-Tissue Mercury Concentrations in the St. Croix River Basin}

Three types of fish-tissue mercury concentrations are discussed in this report. Observed fish-tissue mercury concentrations refer to the measured fish-tissue mercury concentrations in the 193 composite fish-tissue samples collected. Predicted fish-tissue mercury concentrations are the predictions of the recalibrated NDMMF. These predictions can be made for any species and cut combination in the national fish-tissue mercury data set and for any length of fish. However in this 
report, predicted fish-tissue mercury concentrations typically are restricted to species and ranges of fish lengths for each of those species that were captured at each of the $14 \mathrm{St}$. Croix River Basin sampling sites. The lone exception to this restriction is a type of prediction referred to as a standardized fish-tissue mercury concentration. Standardized concentrations are NDMMF predictions of a 14-in. skin-off fillet sample from a largemouth bass (Micropterus salmoides) at each of the 14 sites sampled in the St. Croix River Basin. Standardized concentrations were predicted for sites even if largemouth bass were not captured at the site.

The three types of fish-tissue mercury concentrations serve different purposes in this report. Predicted concentrations are compared to observed concentrations to evaluate how well the model can describe the distribution of fish-tissue mercury concentrations. A good fit at a specific site indicates that the model can be used to produce accurate fish-tissue mercury predictions at that site. Standardized predictions are used to compare fish-tissue mercury concentrations between sites (or across time if sites had been re-sampled over time). Because the effect of sample characteristics has been factored out of the standardized fish-tissue mercury concentrations, standardized concentrations can be compared across sites without the confounding effect of variation in sample characteristics.

\section{Observed Fish-Tissue Mercury Concentrations}

The characteristics of the fish captured at the 14 sampling sites in the St. Croix Basin varied greatly. A total of 62 species were captured at these sites (see table 7 in the "Supplemental Information" section at the back of this report). No species was captured at all sites, and only 19 species occurred at more than one-half of the sites. The species that occurred at the largest number of sampling sites were northern pike, smallmouth bass, and white sucker; each of these species was captured at 12 sites. However, even for those species that occurred at a large number of sites, there were great disparities in the length ranges among sites, with some sites having only small fish and others having only large.

The 193 fish-tissue samples were taken from 37 of the 62 species of fish captured at the St. Croix River Basin sites. The distribution of observed fish-tissue mercury concentrations is presented in figure 2. Fish sampled at the St. Croix River at Prescott (site 14, fig. 1) had the highest median fish-tissue mercury concentrations, and Kinnickinnic River near River Falls (site 13, fig. 1) had the lowest. The range in concentrations was largest for the St. Croix River near Danbury (site 3, fig. 1) and smallest at Kinnickinnic River near River Falls (site 13, fig. 1). The fish-tissue mercury concentrations described here (fig. 2; available at http://waterdata.usgs.gov) are from 37 species of fish, 3 cuts, and lengths from less than 2 to more than 26 in. Direct comparisons among the observed concentrations from these sites are confounded by species, cut, and length effects.

\section{Comparison of Observed and Predicted Fish- Tissue Mercury Concentrations}

The variation in fish characteristics (species, cut, and length) necessitated the use of NDMMF to normalize fishtissue mercury concentrations to a standard set of sample characteristics. Valid predictions can be made for 105 combinations of species and cut for 46 of the 62 species captured at the 14 St. Croix River Basin sites. For 16 of these 62 species, no predictions can be made by NDMMF. Only 27 species can have predictions made for all three of the cuts considered in this report. Figure 3 compares the observed and predicted fishtissue mercury concentrations at each of the 14 St. Croix River Basin sites. The observed concentrations for each species and cut are marked with an "x". The curves in figure 3 are concentration predictions only for those species and cuts of fish sampled at each site (not all species captured at each site). The vertical dashed lines connecting the observed and corresponding predicted value for the same species, cut, and length of fish indicate the residual variation in fish-tissue mercury concentration left unexplained by the model. The horizontal dashed lines at $300 \mu \mathrm{g} / \mathrm{kg}$ (micrograms per kilogram) and $100 \mu \mathrm{g} / \mathrm{kg}$ indicate USEPA's human-health criterion (U.S. Environmental Protection Agency, 2001) and the wildlife health guidance value (Wolfe and Norman, 1998; Yeardley and others, 1998), respectively. Similar graphs can be generated for all sampling events in the national fish-tissue mercury data set on the Environmental Mercury Mapping, Modeling, and Analysis Web site (http://emmma.usgs.govd, which provides public access to NDMMF predictions.

Table 4 shows that for most sites NDMMF predicted fishtissue mercury concentrations matched the observed fish-tissue mercury concentrations (high $\mathrm{R}^{2}$ and low prediction error) over a wide range of observed fish-tissue mercury concentrations (orders of magnitude, table 4). One order of magnitude indicates the concentrations observed at a site vary by a factor of 10 (for example, a range of 10 to $100 \mu \mathrm{g} / \mathrm{kg}$ ). The quality of the fit between the observed and predicted fish-tissue mercury concentrations indicates that NDMMF predictions were accurate for most of the St. Croix River Basin sampling sites.

Because of the diversity of fish species that occurs at these sites, it is often impractical to sample all species, possible cuts, and ranges of fish lengths that occur or could be produced (different cuts) at a site. NDMMF-predicted fish-tissue mercury concentrations can greatly extend the range of species, cuts, and lengths of fish to which fish-tissue mercury concentrations can be validly inferred. This has important implications for fish-consumption advisory development. Column 3 of table 5 indicates the number of species (and name) at each site observed to exceed the human-health criterion. Column 4 of table 5 indicates the number of species (and name) predicted to have at least one cut for that species that would exceed the human-health criterion within the range of fish lengths that were captured at each site. Results of the model-predicted fish-tissue mercury concentrations indicated that more species (the number of species that exceeded the 


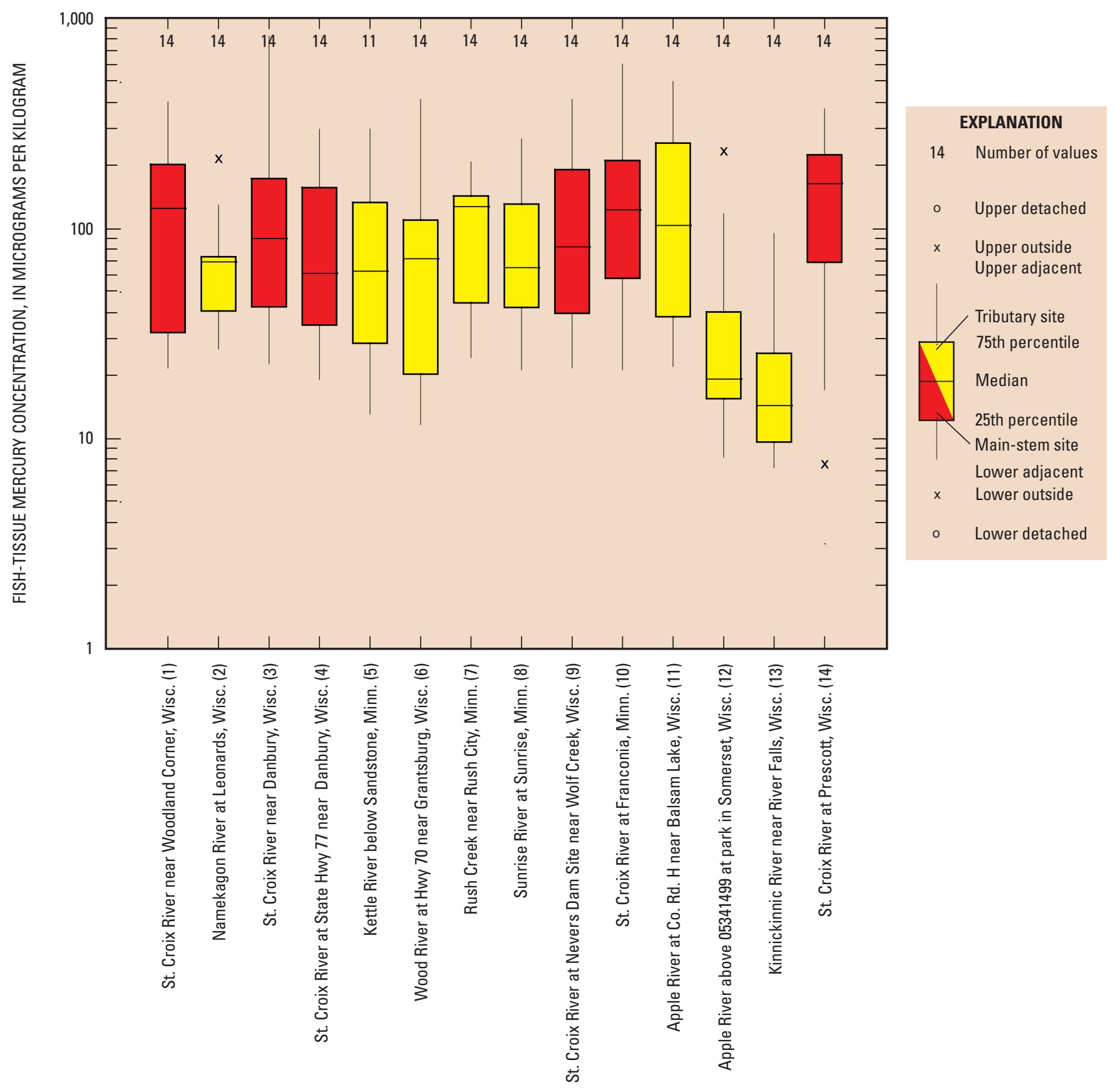

Figure 2. Distribution of observed fish-tissue mercury concentrations for fish collected from the St. Croix River and tributary streams, 2004. (This figure includes data from several species at each site, spanning a range of fish lengths and sample cuts.) 

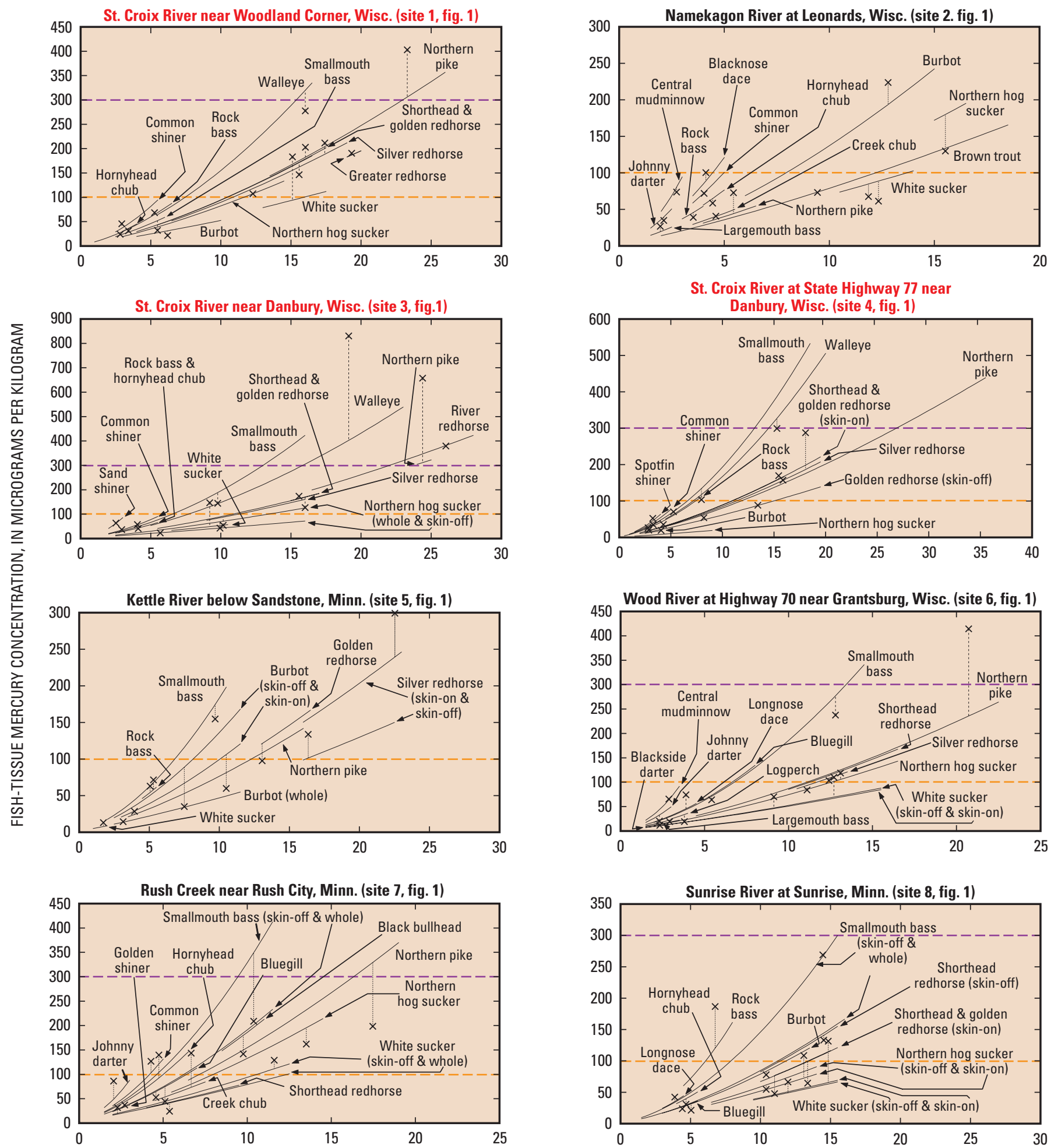

FISH LENGTH, IN INCHES

\section{EXPLANATION}

- - - - U.S. Environmental Protection Agency (2001) human-health criteria

- - - Wildlife health guidance (Wolfe and Norman, 1998; Yeardley and others, 1998)

Figure 3. Comparison of observed (x) to predicted (curves) fish-tissue mercury concentrations for the species and cuts of fish across the range of each species' fish length measured for the site. (Cut only is indicated for these species that were sampled as multiple cuts at the same site; red-titled graphs are main-stem sites.) 

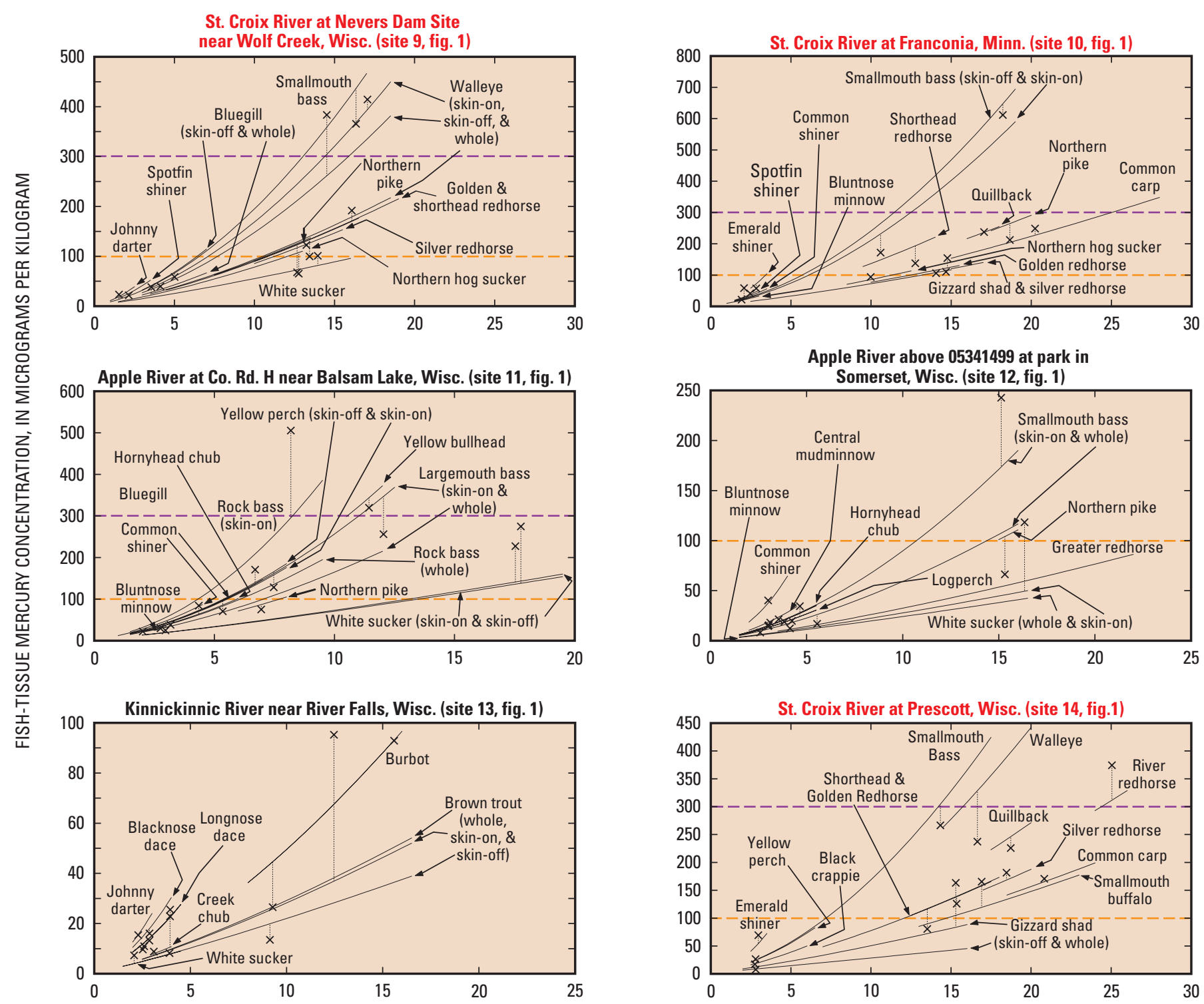

FISH LENGTH, IN INCHES

EXPLANATION

---- U.S. Environmental Protection Agency (2001) human-health criteria

Wildlife health guidance (Wolfe and Norman, 1998; Yeardley and others, 1998)

Figure 3. Comparison of observed (x) to predicted (curves) fish-tissue mercury concentrations for the species and cuts of fish across the range of each species' fish length measured for the site-Continued. (Cut only is indicated for these species that were sampled as multiple cuts at the same site; red-titled graphs are main-stem sites.) 
Table 4. Comparison of model fit $\left(\mathrm{R}^{2}\right)$ and prediction error across a wide range of observed fish-tissue mercury concentrations at each of the 14 sites sampled in the St. Croix River Basin, Minnesota and Wisconsin, 2004.

$\left[\mathrm{R}^{2}\right.$, coefficient of determination (a measure of model fit) calculated from log concentrations]

\begin{tabular}{|c|c|c|c|c|c|}
\hline $\begin{array}{l}\text { Site identi- } \\
\text { fier (fig. 1) }\end{array}$ & Site name & $\begin{array}{c}\text { Number of } \\
\text { samples }\end{array}$ & $\begin{array}{l}\text { Concentration } \\
\text { range (orders of } \\
\text { magnitude) }\end{array}$ & $\mathbf{R}^{2}$ & $\begin{array}{l}\text { Prediction } \\
\text { error } \\
\text { (percent) }\end{array}$ \\
\hline 1 & $\begin{array}{l}\text { St. Croix River near Woodland } \\
\text { Corner, Wisconsin }\end{array}$ & 14 & 1.27 & 0.94 & 22.5 \\
\hline 2 & $\begin{array}{l}\text { Namekagon River at Leonards, } \\
\text { Wisconsin }\end{array}$ & 14 & .92 & .78 & 21.5 \\
\hline 3 & $\begin{array}{l}\text { St. Croix River near Danbury, } \\
\text { Wisconsin }\end{array}$ & 14 & 1.56 & .78 & 41.7 \\
\hline 4 & $\begin{array}{l}\text { St. Croix River at State High- } \\
\text { way } 77 \text { near Danbury, } \\
\text { Wisconsin }\end{array}$ & 14 & 1.19 & .94 & 20.1 \\
\hline 5 & $\begin{array}{l}\text { Kettle River below Sandstone, } \\
\text { Minnesota }\end{array}$ & 11 & 1.36 & .85 & 35.6 \\
\hline 6 & $\begin{array}{l}\text { Wood River at Highway } 70 \text { near } \\
\text { Grantsburg, Wisconsin }\end{array}$ & 14 & 1.55 & .88 & 33.0 \\
\hline 7 & $\begin{array}{l}\text { Rush Creek near Rush City, } \\
\text { Minnesota }\end{array}$ & 14 & .93 & .70 & 39.7 \\
\hline 8 & $\begin{array}{l}\text { Sunrise River near Sunrise, } \\
\text { Minnesota }\end{array}$ & 14 & 1.10 & .75 & 34.2 \\
\hline 9 & $\begin{array}{l}\text { St. Croix River at Nevers Dam } \\
\text { Site near Wolf Creek, } \\
\text { Wisconsin }\end{array}$ & 14 & 1.28 & .91 & 28.2 \\
\hline 10 & $\begin{array}{l}\text { St. Croix River at Franconia, } \\
\text { Minnesota }\end{array}$ & 14 & 1.46 & .90 & 28.8 \\
\hline 11 & $\begin{array}{l}\text { Apple River above } 05341499 \text { at } \\
\text { park in Somerset, Wisconsin }\end{array}$ & 14 & 1.47 & .96 & 35.2 \\
\hline 12 & $\begin{array}{l}\text { Apple River at County Road H } \\
\text { near Balsam Lake, Wisconsin }\end{array}$ & 14 & 1.36 & .89 & 34.7 \\
\hline 13 & $\begin{array}{l}\text { Kinnickinnic River near River } \\
\text { Falls, Wisconsin }\end{array}$ & 14 & 1.12 & .94 & 36.1 \\
\hline \multirow[t]{2}{*}{14} & $\begin{array}{l}\text { St. Croix River near Prescott, } \\
\text { Wisconsin }\end{array}$ & 14 & 1.68 & .95 & 26.7 \\
\hline & Overall & 193 & 2.06 & .89 & 31.6 \\
\hline
\end{tabular}


Table 5. Fish-tissue mercury concentrations exceeding U.S. Environmental Protection Agency's (2001) human-health criterion $(300 \mu \mathrm{g} / \mathrm{kg})$ in the St. Croix River Basin, Minnesota and Wisconsin, 2004.

[NP, northern pike; WE, walleye; B, burbot; RR, river redhorse; SB, smallmouth bass; C, channel catfish; CC, common carp; LB, largemouth bass;

$\mathrm{QB}$, quillback; RB, rock bass; YB, yellow bullhead]

\begin{tabular}{|c|c|c|c|}
\hline $\begin{array}{c}\text { Site } \\
\text { identifier } \\
\text { (fig. 1) }\end{array}$ & Site name & $\begin{array}{l}\text { Number of spe- } \\
\text { cies with observed } \\
\text { exceedances }\end{array}$ & $\begin{array}{l}\text { Number of spe- } \\
\text { cies with predicted } \\
\text { exceedances }\end{array}$ \\
\hline 1 & St. Croix River near Woodland Corner, Wisconsin & $1(\mathrm{NP})$ & $2(\mathrm{NP}, \mathrm{WE})$ \\
\hline 2 & Namekagon River at Leonards, Wisconsin & 0 & $1(\mathrm{~B})$ \\
\hline 3 & St. Croix River near Danbury, Wisconsin & 3 (NP, RR, WE) & $4(\mathrm{NP}, \mathrm{RR}, \mathrm{SB}, \mathrm{WE})$ \\
\hline 4 & St. Croix River at State Highway 77 near Danbury, Wisconsin & 0 & $\begin{array}{l}5 \text { (C, NP, RR, SB, } \\
\text { WE) }\end{array}$ \\
\hline 5 & Kettle River below Sandstone, Minnesota & 0 & 0 \\
\hline 6 & Wood River at Highway 70 near Grantsburg, Wisconsin & $1(\mathrm{NP})$ & $2(\mathrm{SB}, \mathrm{NP})$ \\
\hline 7 & Rush Creek near Rush City, Minnesota & 0 & $2(\mathrm{SB}, \mathrm{NP})$ \\
\hline 8 & Sunrise River near Sunrise, Minnesota & 0 & $1(\mathrm{SB})$ \\
\hline 9 & St. Croix River at Nevers Dam Site near Wolf Creek, Wisconsin & $2(\mathrm{SB}, \mathrm{WE})$ & $3(\mathrm{RR}, \mathrm{SB}, \mathrm{WE})$ \\
\hline 10 & St. Croix River at Franconia, Minnesota & $1(\mathrm{SB})$ & $\begin{array}{l}6(\mathrm{C}, \mathrm{CC}, \mathrm{LB}, \mathrm{NP} \\
\quad \mathrm{QB}, \mathrm{SB})\end{array}$ \\
\hline 11 & Apple River at County Road H near Balsam Lake, Wisconsin & 0 & 0 \\
\hline 12 & Apple River above 05341499 at park in Somerset, Wisconsin & $2(\mathrm{RB}, \mathrm{YB})$ & $3(\mathrm{LB}, \mathrm{RB}, \mathrm{YB})$ \\
\hline 13 & Kinnickinnic River near River Falls, Wisconsin & 0 & 0 \\
\hline \multirow[t]{5}{*}{14} & St. Croix River near Prescott, Wisconsin & $1(\mathrm{RR})$ & $3(\mathrm{RR}, \mathrm{SB}, \mathrm{WE})$ \\
\hline & Totals: & & \\
\hline & Species & 6 & 11 \\
\hline & Sites & 7 & 11 \\
\hline & Species by site & 11 & 32 \\
\hline
\end{tabular}


human-health criterion for at least one site), sites (the number of sites with at least one species exceeding the human-health criterion), and species at sites (the sum across all 14 St. Croix River Basin sites of the number of species exceeding the human-health criterion at each site) exceeded the humanhealth criterion than did observed concentrations.

The observed and predicted values indicated that different species exceeded the human-health criterion at each site. More importantly, every species that was observed to exceed the human-health criterion also was predicted to exceed the human-health criterion. Because of random sampling variation and variation in the fit of the model at different sites, such a high correspondence between observed and predicted exceedances cannot be expected to occur at all sites that might possibly be sampled. However, for sampling events where a good fit is observed between observed and NDMMF-predicted fish-tissue mercury concentrations, these results indicate that NDMMF predictions can be considered a valid method for developing fish-consumption advisories for combinations of sample characteristics that were not sampled.

\section{Standardized Fish-Tissue Mercury Concentrations}

Standardized fish-tissue mercury concentrations estimated by NDMMF are presented in figure 4. No downstream trend in standardized fish-tissue mercury concentration was identified in samples from St. Croix River main-stem sites. Standardized fish-tissue mercury concentrations from Rush Creek near Rush City (site 7, table 1, fig. 1) had the widest range and highest median concentration of the 14 sites sampled. Fish collected at the St. Croix River near Danbury (site 3, table 1, fig. 1) had the widest range in standardized fish-tissue mercury concentrations for the main-stem sites (fig. 4). The highest median fish-tissue mercury concentration for fish sampled from the St. Croix River was for the St. Croix River at Franconia (site 10, table 1, fig. 1). This site is downstream from Rush Creek, a stream with relatively high concentrations of mercury in fish, water, and sediment; however, high fish-tissue mercury concentrations were not observed at the St. Croix River at Nevers Dam Site (site 9, table 1, fig. 1) relative to St. Croix River at Franconia. The St. Croix River at Franconia (site 10, table 1, fig. 1), which is downstream from the Taylors Falls dam, also had modestly higher total mercury and methylmercury concentrations in the water column (Payne and Hansen, 2003) compared to the Nevers Dam Site (site 9, table 1, fig. 1). Although higher methylmercury concentrations in the water column would lead to higher fish-tissue mercury concentrations (Wiener and others, 2002), further sampling across a range of flow conditions and seasons would be needed to demonstrate a significant difference in watercolumn mercury and methylmercury concentrations between the two sites.
Samples from the Apple River at County Road H near Balsam Lake (site 11, table 1, fig. 1) also had higher standardized concentrations and a wider range of standardized concentrations in contrast to a downstream site, Apple River in Somerset (site 12, table 1, fig. 1). Several low-head dams on the Apple River between Balsam Lake and Somerset may impede fish migration between the two reaches. In addition, the Apple River drainage has numerous lakes and impoundments, so that higher methylmercury concentrations in the upstream reaches of the watershed might be removed effectively in the lakes and impoundments, yielding lower concentrations in the downstream end of the Apple River in Somerset.

The data from Rush Creek near Rush City (site 7, fig. 1) provide an example of how NDMMF makes it easier to identify significant spatial trends in the data. Samples from this site had the highest standardized median fish-tissue mercury concentration and also had the highest sediment mercury concentrations (Brigham, 2002) and water methylmercury concentration (Payne and Hanson, 2003). However, samples from the Rush Creek near Rush City site also had the poorest model fit (lowest $\mathrm{R}^{2}$ ) in table 4. Further, this site is on a small stream near its confluence with the much larger St. Croix River (fig. 1); therefore, many of the larger fish sampled here probably spent considerable time in the St. Croix River away from the relatively higher mercury-concentration environment of Rush Creek.

The graph in figure $5 A$ was prepared by using NDMMF to predict a standardized fish-tissue mercury concentration (14-in., largemouth bass, skin-off fillet) for each fish sample collected from Rush Creek near Rush City and three nearby sites (fig. $5 B$ ). The size of the circle represents the number of fish in the composite sample. The graph (fig. 5A) shows the smallest fish sampled from Rush Creek tended to reflect the higher mercury-concentration environment of Rush Creek in standardized fish-mercury concentrations, whereas the larger fish tended to reflect the upstream and downstream St. Croix mercury concentrations. The Sunrise River samples (site 8, fig. 1) from close to its confluence with the St. Croix showed a similar pattern with the exception that samples from small fish had low fish-tissue mercury concentrations whereas samples from larger fish again reflected mercury concentrations similar to samples from St. Croix River fish.

This example illustrates how NDMMF predictions can be useful for management purposes even at sites where NDMMF fits poorly. The relatively poorer model fit at the Rush Creek site (site 7, table 4) indicated that additional analysis was needed (such as that presented in figure 5) to better manage fish-tissue mercury issues at this site. The average standardized fish-tissue mercury concentration would underestimate the degree of contamination at the site (indicated by the small fish, fig. 5A) and overestimate the threat to fish consumers (who eat the larger game fish). 


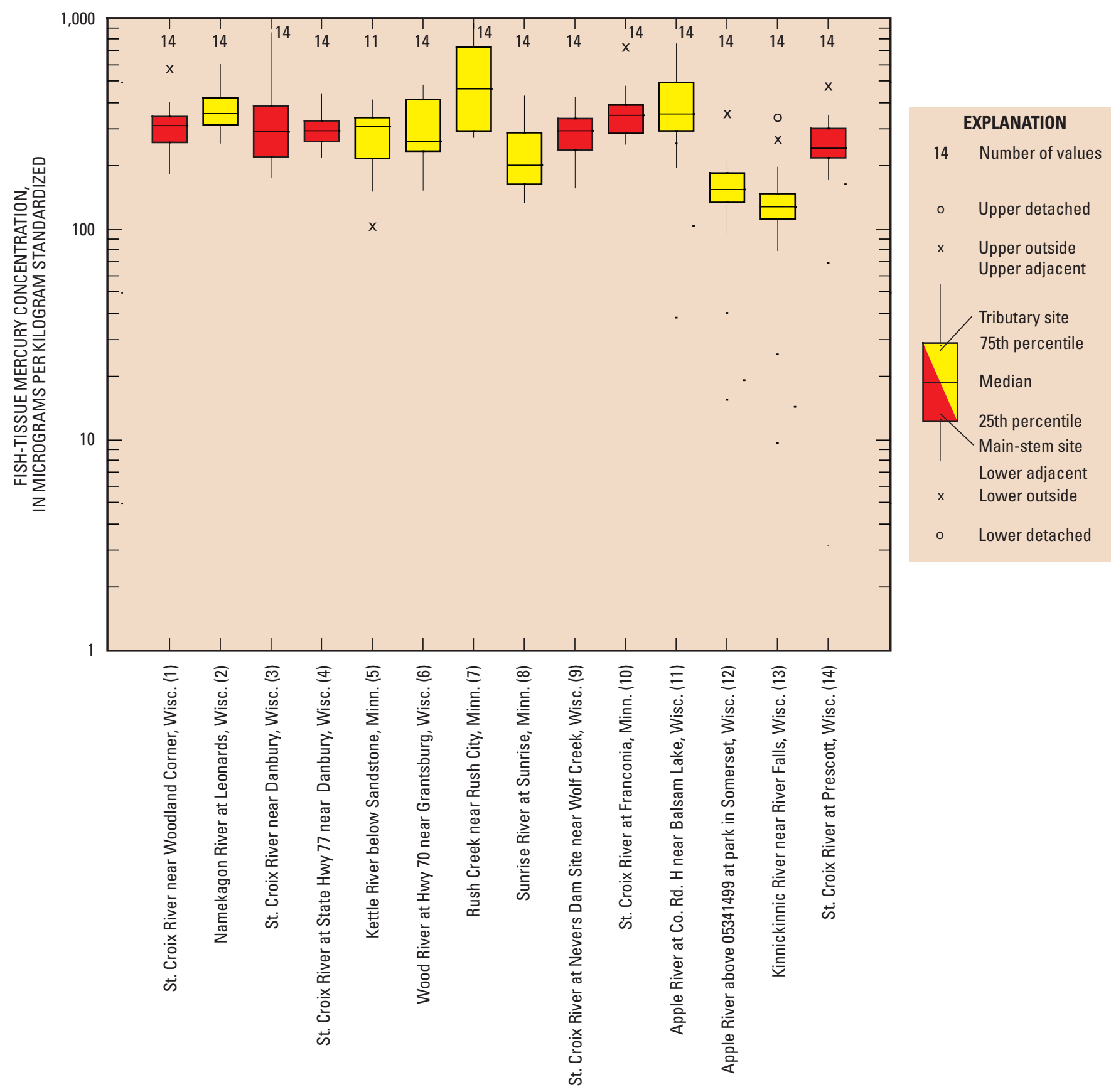

Figure 4. Distribution of standardized fish-tissue mercury concentrations for fish collected from the St. Croix River and tributary streams, 2004. (Standardized fish-tissue mercury concentrations are predicted for 14-inch largemouth bass skin-off fillet tissue using the National Descriptive Model for Mercury in Fish.) 
A.

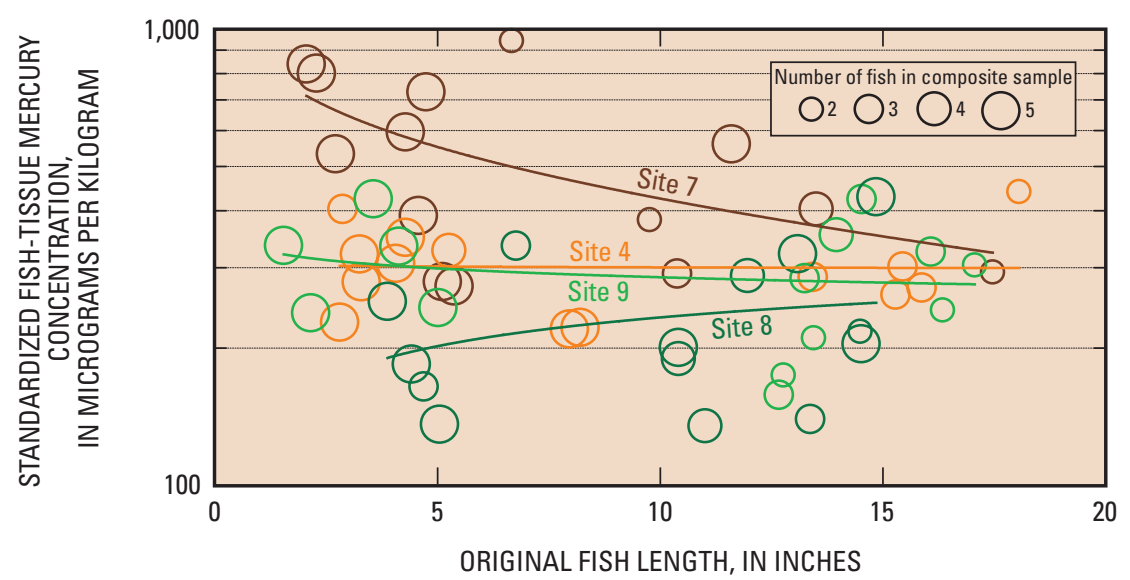

B.

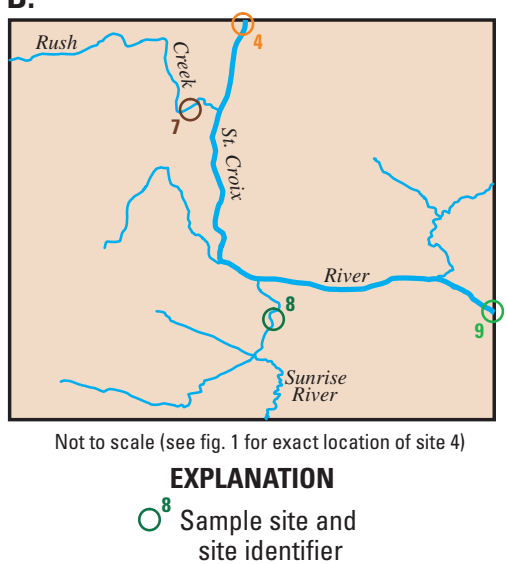

Figure 5. Comparison of standardized fish-tissue mercury concentrations from four sites sampled in the St. Croix River Basin, 2004. (Standardized fish-tissue mercury concentrations are predicted for 14-inch largemouth bass skin-off fillet tissue using the National Descriptive Model for Mercury in Fish.)

\section{Relation of Standardized Fish-Tissue Mercury Concentrations to Land Use in the St. Croix River Basin}

Land use in the St. Croix River Basin (table 1) varies from primarily forested in the northern part of the basin to primarily agricultural in the south. The four sites with the highest median standardized fish-tissue mercury concentrations (Namekagon River at Leonards, Rush Creek near Rush City, St. Croix River at Franconia, and Apple River near Balsam Lake, sites 2, 7, 10,11, respectively) did not have many similarities in land use. These sites were distributed across the basin and, therefore, showed no spatial relation with the exception of the St. Croix River at Franconia (site 10, fig. 1), which is downstream from Rush Creek near Rush City (site 7, fig. 1); the concentrations of fish-tissue mercury at these two sites may be related. It also is possible that these two sites are not related because the high fish-tissue mercury concentrations in samples from the Franconia site may be due to discharges from the upstream cities of Taylors Falls, Minnesota, and (or) St. Croix Falls, Wisconsin, and possible effects of the Taylors Falls dam.

Although little similarity was evident for the sites with high fish-tissue mercury concentrations, sites with low fish- tissue mercury concentrations had some similarities. The two sites with the lowest median standardized fish-tissue mercury concentrations (Apple River above 05341499 at park in Somerset, site 12, and Kinnickinnic River near River Falls, site 13, fig. 4) also had the highest percentage of agricultural land use and the lowest percentage of wetlands. These two sites also had a relatively small percentage of forested land. Sunrise River at Sunrise (site 8, fig. 4), a site with a low median fish-tissue mercury concentration, had a large percentage of agricultural land use but had substantial wetland abundance (26 percent, table 1 ).

Wetlands can act as a sink for total mercury and a source for methylmercury (St. Louis and others, 1994, 1996; Chavan, 2005). Because methylmercury is the form that accumulates in fish, higher fish-tissue mercury concentrations may be a concern downstream from wetlands. Therefore, the percentage of watershed in wetlands and the median standardized fishtissue mercury concentration were compared with a Wilcoxon rank-sum test. There was no significant difference in median fish-tissue mercury concentrations between sites with greater than 10 percent of the watershed in wetlands and those sites draining less than 10 percent wetlands. The lack of a significant relation may be due mainly to one outlier (Rush Creek near Rush City, site 7). 
Sampling sites were grouped into those that drained forest/wetland areas (St. Croix River near Woodland Corner, Namekagon River at Leonards, and St. Croix River near Danbury, sites 1-3, fig. 1) and those that drained agricultural/forest sites (Kettle River below Sandstone, Wood River at Highway 70 near Grantsburg, St. Croix River at Franconia, Apple River at County Road H near Balsam Lake, Apple River in Somerset, and St. Croix River at Prescott, sites 5-6, 10-12, 14, fig. 1). The sites that drained agricultural (Kinnickinnic River near River Falls, site 13) or agricultural/wetland (Rush Creek near Rush City and Sunrise River at Sunrise, sites 7-8) were not used in the analysis. A Wilcoxon rank-sum test indicated that sites draining forest/wetland watersheds had significantly higher median standardized fish-tissue mercury concentrations than sites draining agricultural/forested watersheds $(p=0.0003)$. Land use often is related to geology and climate and, therefore, to soil properties and water quality. Therefore, any empirical relation between land use and fish-tissue mercury concentrations may be due to other factors that are related to land use.

\section{Relation of Standardized Fish-Tissue Mercury Concentrations to Water and Sediment Mercury Concentrations}

Standardized fish-tissue mercury concentrations determined for this study were compared to total mercury and methylmercury concentrations in water (Payne and Hansen, 2003), and mercury concentrations in sediment (Brigham, 2002). Water-sample analyses were available for 13 of the 14 sites where fish were collected (the exception being Apple River at County Road H near Balsam Lake, site 11). Sediment samples were collected either at (10 sites) or very near (4 sites) all 14 sites where fish were collected. In addition, water samples were collected in 2004 as part of the NAWQA Program. A comparison of fish-tissue mercury concentrations to water and sediment mercury concentrations is shown in table 6.

The significance of the association between standardized fish-tissue mercury and the concentration of total mercury in water was measured by Spearman's rho. Rho is resistant to the effects of outliers; the fish-tissue mercury, total mercury, methylmercury, and sediment mercury concentrations in samples from Rush Creek (site 7, fig. 1, table 1) are outlier values that can affect other measures of correlation.

The most significant relation was between standardized fish-tissue mercury concentration and methylmercury concentration in water $(\mathrm{rho}=0.580, \mathrm{p}=0.02)$. The relation between standardized fish-tissue mercury and mercury in sediment also was significant ( $r h o=0.569, \mathrm{p}=0.03$ ). The relation between standardized fish-tissue mercury concentration and total mercury in water was not significant ( $\mathrm{rho}=0.278, \mathrm{p}=0.47$ ). These relations are based on 2000-01 total and methylmercury concentrations and 2000 sediment mercury concentrations.
The relations are expected because methylmercury is the form of mercury that accumulates in fish and sites with high concentrations of methylmercury likely have high fish-tissue concentrations. However, the variation between 2000-01 and 2004 methylmercury concentrations was substantial for some sites (for example, Kettle River below Sandstone and Rush Creek near Rush City, site 5 and 7, table 6).

\section{Implications}

Fish-tissue mercury concentrations varied considerably within the St. Croix River Basin with median standardized fish-tissue mercury concentrations varying from $129 \mu \mathrm{g} / \mathrm{kg}$ at Kinnickinnic River near River Falls (site 13) to $468 \mu \mathrm{g} / \mathrm{kg}$ at Rush Creek near Rush City (site 7). Although some sites may be affected by local sources of mercury that potentially could be remediated by site-specific methods, many sites in the St. Croix Basin appear to have high fish-tissue mercury concentrations due to some combination of natural features (prevalence of wetlands) and atmospheric deposition of mercury from distant sources (Fitzgerald and others, 1998). Geologic sources of mercury are not supported by geochemical data (Cannon and Woodruff, 2003). Because A-horizon soils in the St. Croix River Basin (Cannon and Woodruff, 2003) and in the region (Woodruff and others, 2002, 2003) have higher mercury concentrations than C-horizon soils, it is not likely that the source of the mercury is the underlying geology.

On the basis of NDMMF predictions, 11 of the 14 sites sampled had fish-tissue mercury concentrations that were high enough to potentially warrant the issuance of fish-consumption advisories. Although remediation of local anthropogenic sources could produce some reduction in fish-tissue mercury concentrations, it is unlikely that remediation of local anthropogenic mercury sources would result in a substantial reduction in the number and spatial extent of sites that might warrant fish-tissue consumption advisories in the St. Croix River Basin if it is assumed that much of the widespread fishtissue mercury is due to atmospheric deposition from remote sources.

The 2004 sampling of fish-tissue mercury concentrations from the St. Croix River Basin in this report would serve as a good baseline from which to assess effectiveness of reduced atmospheric inputs of mercury in the St. Croix River Basin. Because many of the sites sampled yielded small prediction errors when fit to NDMMF, future re-samplings of these sites likely would provide a sensitive measure of changes in fish-tissue mercury concentrations, assuming that future data from these sites fit NDMMF equally well.

Often stream, river, or lake sites are inhabited by a large number of fish species even if only game fish are considered. Sampling plans typically constrain the number of species, cuts, and size class (lengths) combinations (especially considering sample replication requirements) sampled at each 


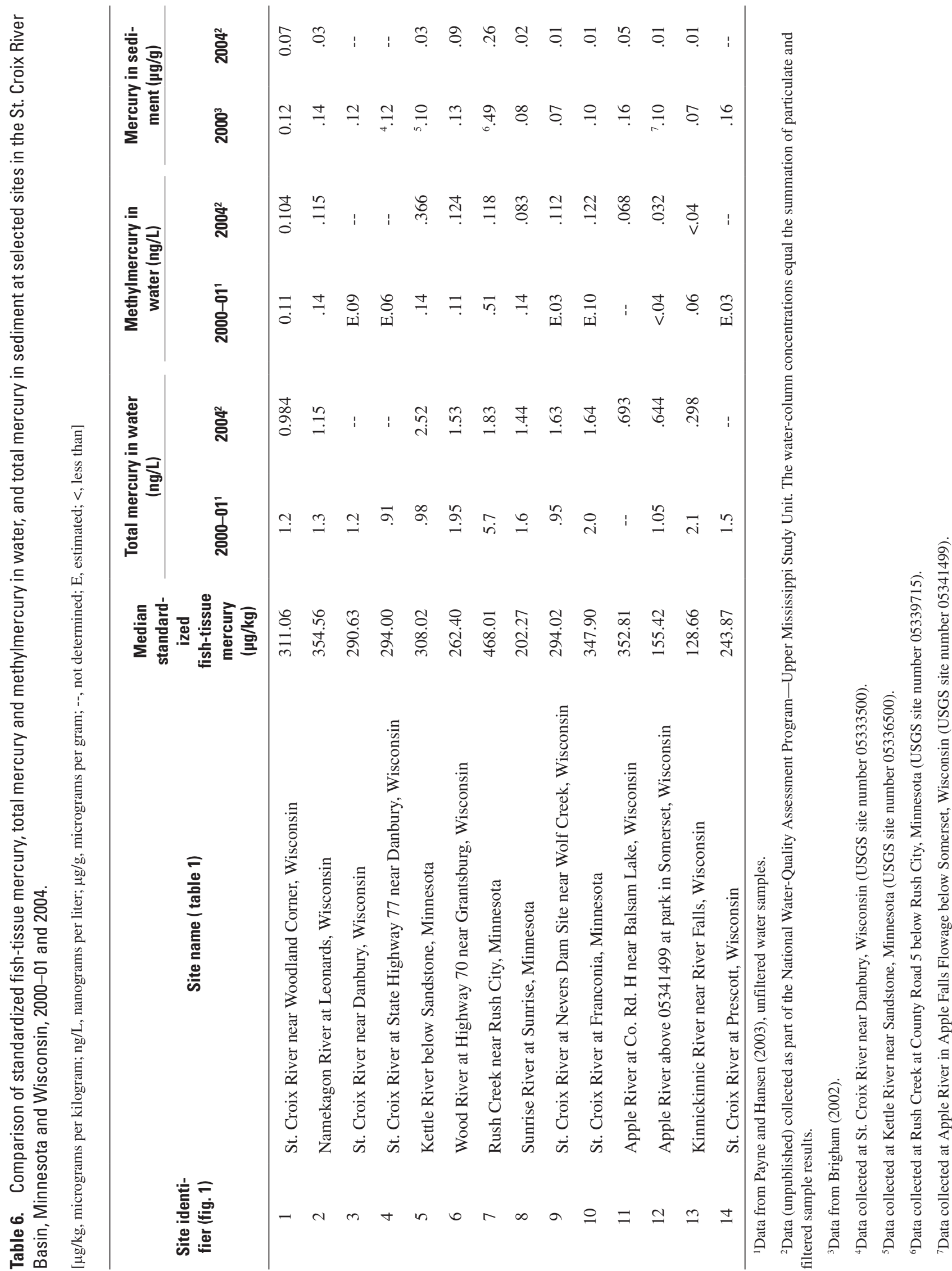


site to only a small fraction of the combinations of sample characteristics (species, cuts, and lengths of fish) that occur at each site. Therefore, fish consumption advisories that are based solely on observed fish-tissue mercury concentrations may not provide enough information to fully advise fish consumers of potential health risks. The quality of the fit between the observed and predicted fish-tissue mercury concentrations over the wide range of characteristics sampled at each St. Croix River Basin site indicates that NDMMF should be considered a valid method for predicting fish-tissue mercury concentrations especially for species, cut, and length combinations that are not sampled during sampling events.

\section{Summary}

The St. Croix River is one of several National Scenic Riverways managed by the National Park Service. On the basis of observed fish-tissue mercury concentrations from the St. Croix River, the States of Minnesota and Wisconsin have issued fish-consumption advisories for portions of the river. Mercury contamination is a concern for humans who consume fish and possibly for the health of fish-eating wildlife. Mercury contamination of the aquatic ecosystem has been identified as one of the most serious aquatic resource concerns in the St. Croix River Basin and in the riverway. The U.S. Geological Survey, National Park Service, and University of Wisconsin, LaCrosse, cooperated in the study to determine the spatial variation of mercury in fish in the St. Croix River and selected tributaries.

Game and nongame fish species were collected and identified at 14 sites during summer 2004. One hundred ninety-three (193) composite tissue samples were analyzed for total mercury as whole fish, skin-on fillet, or skin-off fillet. Observed fish-tissue mercury concentrations exceeding the U.S. Environmental Protection Agency (USEPA) humanhealth criterion of $300 \mathrm{mg} / \mathrm{kg}$ occurred at 7 of the 14 sampling sites.

A national descriptive model of mercury in fish was used to predict fish-tissue mercury concentrations at each of the 14 St. Croix River Basin sites. The model predicted a concentration exceeding USEPA's fish criterion at all of the seven sites where exceedances were observed and four of the seven sites where exceedances were not observed. The implication is that fish-consumption advisories that are based solely on observed concentrations could underestimate the threat to human health. A national descriptive model to predict fish-tissue mercury concentrations could be a useful tool for developing site-specific fish-consumption advisories relative to multiple species, lengths, and cuts of fish. For example, fish consumers could choose to consume sizes and species of fish that are expected to have lower fish-tissue mercury concentrations on the basis of this information.

A national descriptive model of mercury in fish was used to standardize fish-tissue mercury concentrations to a specific species, cut, and length of fish (14-in. largemouth bass, skin-off fillet) so that valid comparisons of fish-tissue mercury concentrations could be made among St. Croix River Basin sites. No downstream trend in standardized fish-tissue mercury concentration was identified in samples from St. Croix River main-stem sites. Rush Creek near Rush City, Minnesota, was identified as having high median standardized fish-tissue mercury concentrations. Previous studies identified Rush Creek as having relatively high concentrations of methylmercury in water and high concentrations of mercury in sediment when compared to other sites in the St. Croix River Basin.

Land-cover characteristics of the area upstream from each site were compared to standardized fish-tissue mercury concentrations. A Wilcoxon rank-sum test indicated that sites draining forest/wetland watersheds had significantly higher median fish-mercury concentrations than sites draining agricultural/forested watersheds $(\mathrm{p}=0.0003)$.

Comparisons also were made between median standardized fish-tissue mercury concentrations (this report) and total mercury and methymercury in water and total mercury in sediment (two previous studies). The most significant relation was between fish-tissue mercury concentration and methylmercury concentration in water $(\mathrm{rho}=0.580, \mathrm{p}=0.02)$. The relation between fish-tissue mercury and mercury in sediment also was significant ( $\mathrm{rho}=0.569, \mathrm{p}=0.03$ ).

Many of the sites sampled in the St. Croix River probably have high fish-tissue mercury concentrations due to a combination of natural factors and atmospheric deposition. The 2004 sampling of fish-tissue mercury concentrations described in this report could serve as a baseline to assess progress in controlling atmospheric mercury emissions and subsequent deposition within the basin.

\section{References}

Anderson, P., and Varro, J., 2002, The state of the St. Croix Basin-an integrated resource management plan: Wisconsin Department of Natural Resources, PUBL WT-555-2002, $139 \mathrm{p}$.

Barr, J.F., 1986, Population dynamics of the common loon (Gavia immer) associated with mercury-contaminated waters in northwestern Ontario: Canadian Wildlife Service, Occasional Paper 56, 25 p.

Bloom, N.S., and Watras, C.J., 1989, Observations of methylmercury in precipitation: The Science of the Total Environment, v. 87/88, p. 199-207.

Boudou, A., and Ribeyre, F., 1983, Contamination of aquatic biocenoses by mercury compounds - an experimental ecotoxicological approach, in Nriagu, J.O., ed., Aquatic toxicology: New York, John Wiley and Sons, p. 73-116.

Brigham, M.E., 2002, Elemental chemistry of streambed sediments of the St. Croix River Basin, 2000: U.S. Geological Survey Open-File Report 02-4087, 19 p. 
Cannon, W.F., and Woodruff, L.G., 2003, The geochemical landscape of northwestern Wisconsin and adjacent parts of northern Michigan and Minnesota: U.S. Geological Survey Open-File Report 03-259, geochemical data files.

Chavan, P.V., 2005, Assessment of mercury transformation in constructed wetlands: Geological Society of America 101 ${ }^{\text {st }}$ Annual Meeting, April 29-May 1, 2005, San Jose, California, in Abstracts with Programs, v. 37, no. 4, p. 105.

Compeau, G.C., and Bartha, R., 1985, Sulfate-reducing bacteria-principal methylators of mercury in anoxic estuarine sediment: Applied and Environmental Microbiology, v. 50, no. 2, p. 498-502.

Cope, W.G., Wiener, J.G., and Rada, R.G., 1990, Mercury accumulation in yellow perch in Wisconsin seepage lakesrelation to lake characteristics: Environmental Toxicology and Chemistry, v. 9, no. 7, p. 931-940.

Fago, D., and Hatch, J., 1993, Aquatic resources of the St. Croix River Basin, in Hesse, L.W., Stalnaker, C.B., Benson, N.G., and Zuboy, J.R., eds., Proceedings of the Symposium on Restoration Planning for the Rivers of the Mississippi River Basin: Washington, D.C., U.S., Department of the Interior, National Biological Service Report 19, p. 23-56.

Fallon, J.D., and McNellis, R.P., 2000, Nutrients and suspended sediment in snowmelt runoff from part of the upper Mississippi River Basin, Minnesota and Wisconsin, 1997: U.S. Geological Survey Water-Resources Investigations Report 00-4165, 23 p.

Fitzgerald, W.F., Engstrom, D.R., Mason, R.P., and Nater, E.A., 1998, The case for atmospheric mercury contamination in remote areas: Environmental Science and Technology, v. 32, no. 1, p. 1-7.

Friedmann, A.S., Watzin, M.C., Brinck-Johnsen, T., and Leiter, J.C., 1996, Low levels of dietary methylmercury inhibit growth and gonadal development in juvenile walleye (Stizostedion vitreum): Aquatic Toxicology, v. 35, p. 265278.

Giblin, F.J., and Massaro, E.J., 1973, Pharmacodynamics of methyl mercury in the rainbow trout (Salmo gairdneri) tissue uptake, distribution and excretion: Toxicology and Applied Pharmacology, v. 24, no. 1, p. 81-91.

Gilmour, C.C., Riedel, G.S., Ederington, M.C., Bell, J.T., Benoit, J.M., Gill, G.A., and Stordal, M.C., 1998, Methylmercury concentrations and production rates across a trophic gradient in the northern Everglades: Biogeochemistry, v. 40, nos. 2-3, p. 327-345.
Harrison, S.E., Klaverkamp, J.F., and Hesslein, R.H., 1990, Fates of metal radiotracers added to a whole lake-accumulation in fathead minnow (Pimephales promelas) and lake trout (Salvelinus namaycush): Water, Air, and Soil Pollution, v. 53, no. 3-4, p. 277-293.

Hem, J.D., 1992, Study and interpretation of the chemical characteristics of natural water: U.S. Geological Survey Water-Supply Paper 2254, p. 142.

Hitt, K.J., 1991, Digital map file of major land uses in the United States: U.S. Geological Survey, Reston, Virginia, scale 1:750,000.

Hitt, K.J., 1994, Refining 1970's land-use data with 1990 population data to indicate new residential development: U.S. Geological Survey Water-Resource Investigations Report 94-4250, 15 p.

Holmberg, K.L., Perry, Jim, Ferrin, R.S., and Sharrow, D.L., 1997, Water resources plan-St. Croix National Scenic Riverway, Minnesota and Wisconsin: St. Croix Falls, Wisconsin, National Park Service, 155 p.

Hurley, J.P., Benoit, J.M., Shafer, M.M., Andren, A.W., Sullivan, J.R., Hammond, R., and Webb, D.A., 1995, Influences of watershed characteristics on mercury levels in Wisconsin rivers: Environmental Science and Technology, v. 29, no. 7, p. $1867-1875$.

Kim, J.P., and Burggraaf, S., 1999, Mercury bioaccumulation in rainbow trout (Onocorhynchus mykiss) and the trout food web in lakes Okareka, Okaro, Tarawera, Rotomahana and Rotorua, New Zealand: Water, Air, and Soil Pollution, v. 115 , p. $535-546$.

MacCrimmon, H.R., Wren, C.D., and Gots, B.L., 1983, Mercury uptake by lake trout, Salvelinus namaycush, relative to age growth, and diet in Tadenac Lake with comparative data from other Precambrian Shield Lakes: Canadian Journal of Fisheries and Aquatic Sciences, v. 40, no. 2, p. 114-120.

Meyer, M.W., Evers, D.C., Hartigan, J.J., and Rasmussen, P.S., 1998, Patterns of common loon (Gavia immer) mercury exposure, reproduction, and survival in Wisconsin, USA: Environmental Toxicology and Chemistry, v. 17, no. 2, p. 184-190.

Minnesota Department of Health, 2000, Minnesota fish consumption advisory: St. Paul, Minnesota, Annual advisory booklet, $100 \mathrm{p}$.

Montz, G.R., Renard, P.A., Hanson, S.R., and Enblom, J.R., 1989, Biological survey of the St. Croix River, 1988-1989: Minnesota Department of Natural Resources Internal Report, variously paged. 
Morel, F.M.M., Kraepiel, A.M.L., and Amyot, M., 1998, The chemical cycle and bioaccumulation of mercury: Annual Review of Ecology and Systematics, v. 29, p. 543-566.

Ojakangas, R.W., and Matsch, C.L., 1982, Minnesota's geology: Minneapolis, Minnesota, University of Minnesota Press, 255 p.

Payne, G.A., and Hansen, D.S., 2003, Reconnaissance of mercury and methylmercury in the St. Croix River and selected tributaries, July 2000 through October 2001: U.S. Geological Survey Water-Resources Investigations Report 03-4223, $9 \mathrm{p}$.

Payne, G.A., Lee, K.E., Montz, G.R., Talmage, P.J., Hirsch, J.K., and Larson, J.D., 2002, Water-quality and aquaticcommunity characteristics of selected reaches of the St. Croix River, Minnesota and Wisconsin, 2000: U.S. Geological Survey Water-Resources Report 02-4147, p. 3-4.

SAS Institute, Inc., 1989, SAS/STAT User's guide (4th ed.): Cary, North Carolina, SAS Institute, Inc., v. 2, version 6 , $795 \mathrm{p}$.

Schroeder, W.H., and Munthe, J., 1998, Atmospheric mercury-an overview: Atmospheric Environment, v. 32, no. 5, p. 809-822.

Schwarz, G.E., Hoos, A.B., Alexander, R.B., and Smith, R.A., 2006, The SPARROW surface water-quality model-theory, application, and user documentation: U.S. Geological Survey Techniques and Methods Report 6-B3.

Shubat, P., Staba, M., and Carpenter, H., 1995, Criteria used to issue fish consumption advice-1995 Minnesota fish consumption advisory: Minnesota Department of Health, HRA Series FSH-95-001, variously paged.

St. Louis, V.L., Rudd, J.W.M., Kelly, C.A., and Beaty, K.G., 1996, Production and loss of methylmercury and loss of total mercury from boreal forest catchments containing different types of wetlands: Environment Science and Technology, v. 30, p. 2719-2729.

St. Louis, V.L., Rudd, J.W.M., Kelly, C.A., Beaty, K.G., Bloom, N.S., and Flett, R.J., 1994, Importance of wetlands as sources of methylmercury to boreal forest ecosystems: Canadian Journal of Fisheries and Aquatic Sciences, v. 51, p. 1065-1076.

Suns, K., Hitchin, G., Loescher, B., Pastorek, E., and Pearce, R., 1987, Metal accumulations in fishes from Muskoka-Haliburton Lakes in Ontario (1978-1984): Rexdale, Ontario, Ontario Ministry of the Environment, 38 p.

U.S. Environmental Protection Agency, 2001, Water quality criterion of the protection of human health-methylmercury: Washington, D.C., U. S. Environmental Protection Agency, Office of Science and Technology, EPA-823-R01-001, variously paged.
U.S. Environmental Protection Agency, 2002, Method 1631, Revision E-mercury in water by oxidation, purge and trap, and cold vapor atomic fluorescence spectrometry: Washington, D.C., U.S. Environmental Protection Agency Office of Water, EPA-821-R-02-019, 38 p.

Watras, C.J., and Bloom, N.S., 1992, Mercury and methylmercury in individual zooplankton-implications for bioaccumulation: Limnology and Oceanography, v. 37, no. 6, p. 1313-1318.

Wente, S.P., 2004, A statistical model and national data set for partitioning fish-tissue mercury concentration variation between spatiotemporal and sample characteristic effects: U.S. Geological Survey Scientific Investigation Report 2004-5199, 15 p.

Wetzel, R.G., 2001, Limnology lake and river ecosystems (3d ed.): San Diego, California, Academic Press, 309 p.

Wiener, J.G., Krabbenhoft, D.P., Heinz, G.H., and Scheuhammer, A.M., 2002, Ecotoxicology of mercury, chapter 16, in Hoffman, D.J., Rattner, B.A., Burton, G.A., Jr., and Cairns, J., ed., Handbook of ecotoxicology ( $2^{\text {nd }}$ ed.): Boca Raton, Florida, CRC Press, p. 409-463.

Wisconsin Division of Health, 2000, Important health information for people eating fish from Wisconsin waters: Pub. No. FH824 00Rev., 59 p.

Wolfe, M., and Norman, Donald, 1998, Effects of waterborne mercury on terrestrial wildlife at Clear Lake-evaluation and testing of a predictive model: Environmental Toxicology and Chemistry, v. 17, no. 2, p. 214-227.

Woodruff, L.G., Cannon, W.F., Dicken, C.L., Bennett, J.P., and Nicholson, S.W., 2003, Bedrock, soil, and lichen geochemistry from Isle Royale National Park, Michigan: U.S. Geological Survey Open-File Report 03-276, 17 p., geochemical data files.

Woodruff, L.G., Cannon, W.F., Dicken, C.L., and Pimley, Shana, 2002, Bedrock and soil geochemistry from Voyageurs National Park, Minnesota: U.S. Geological Survey Open-File Report 02-196, 8 p., 1 over-sized sheet, available at http://pubs.usgs.gov/of/2002/of02-196.

Yeardley, R.B., Jr., Lazorchak, J.M., and Paulens, S.G., 1998, Elemental fish tissue contamination in northeastern U.S. lakes-evaluation of an approach to regional assessment: Environmental Contamination and Toxicology, v. 17, no. 9, p. 1875-1884. 


\section{Supplemental Information}




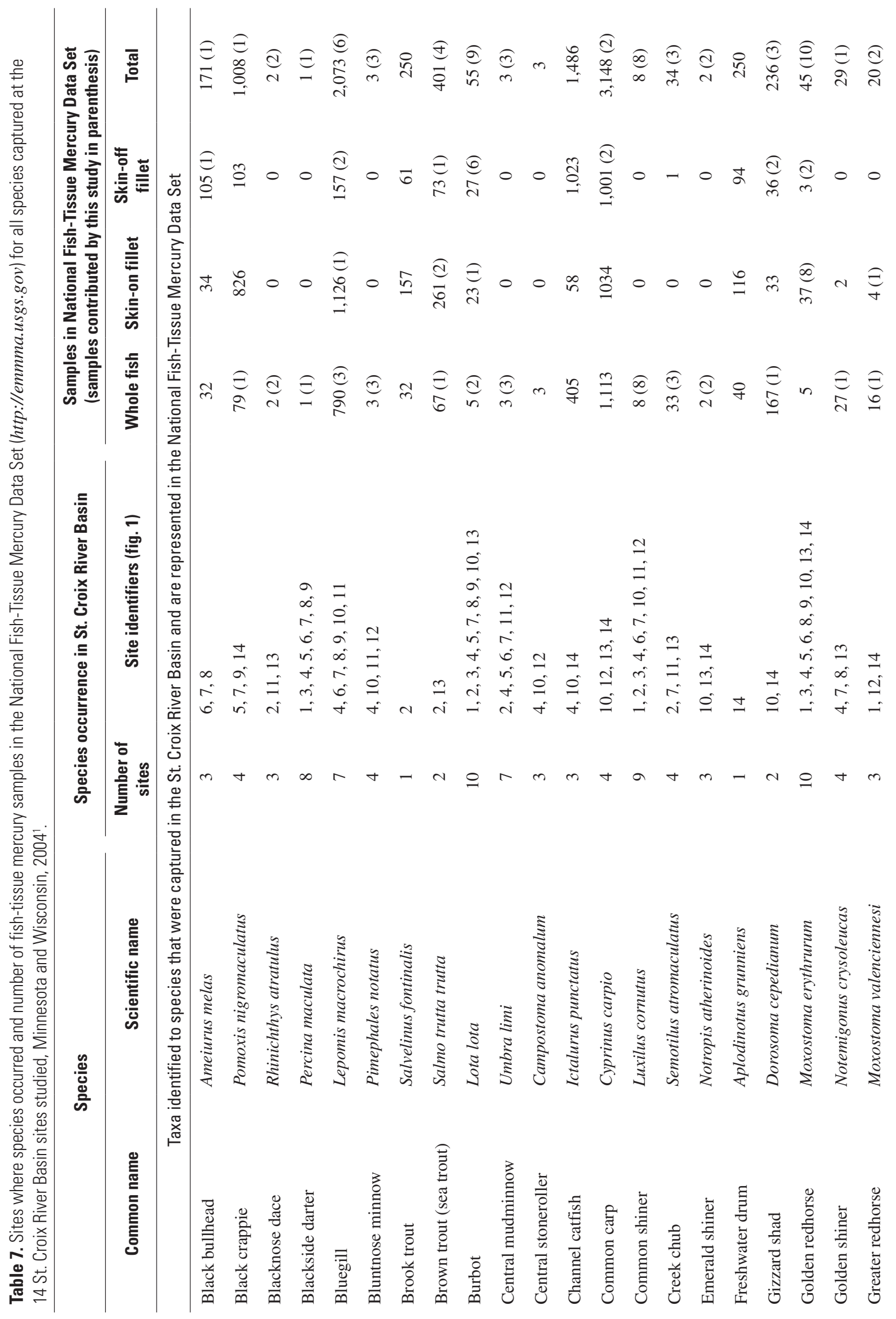




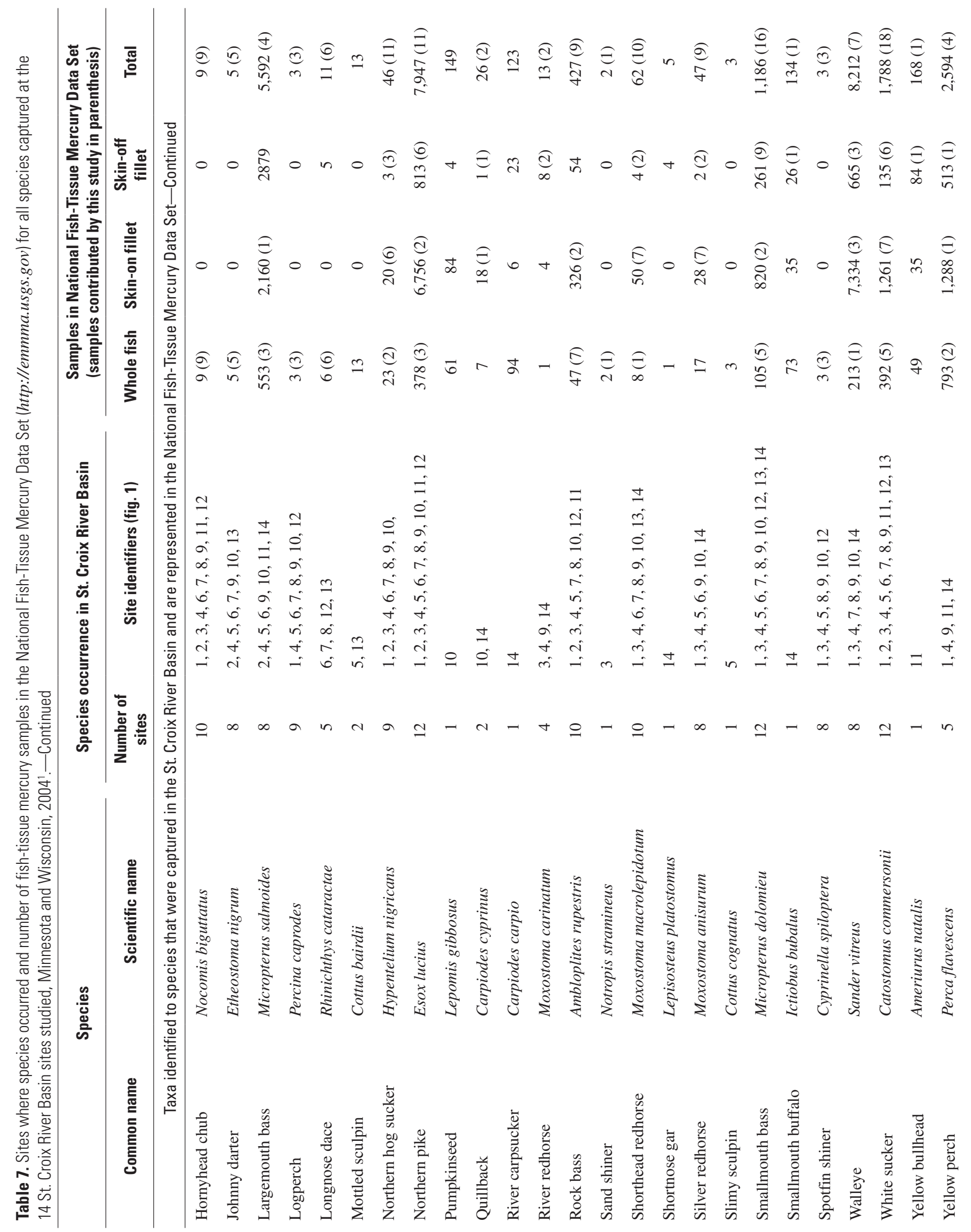




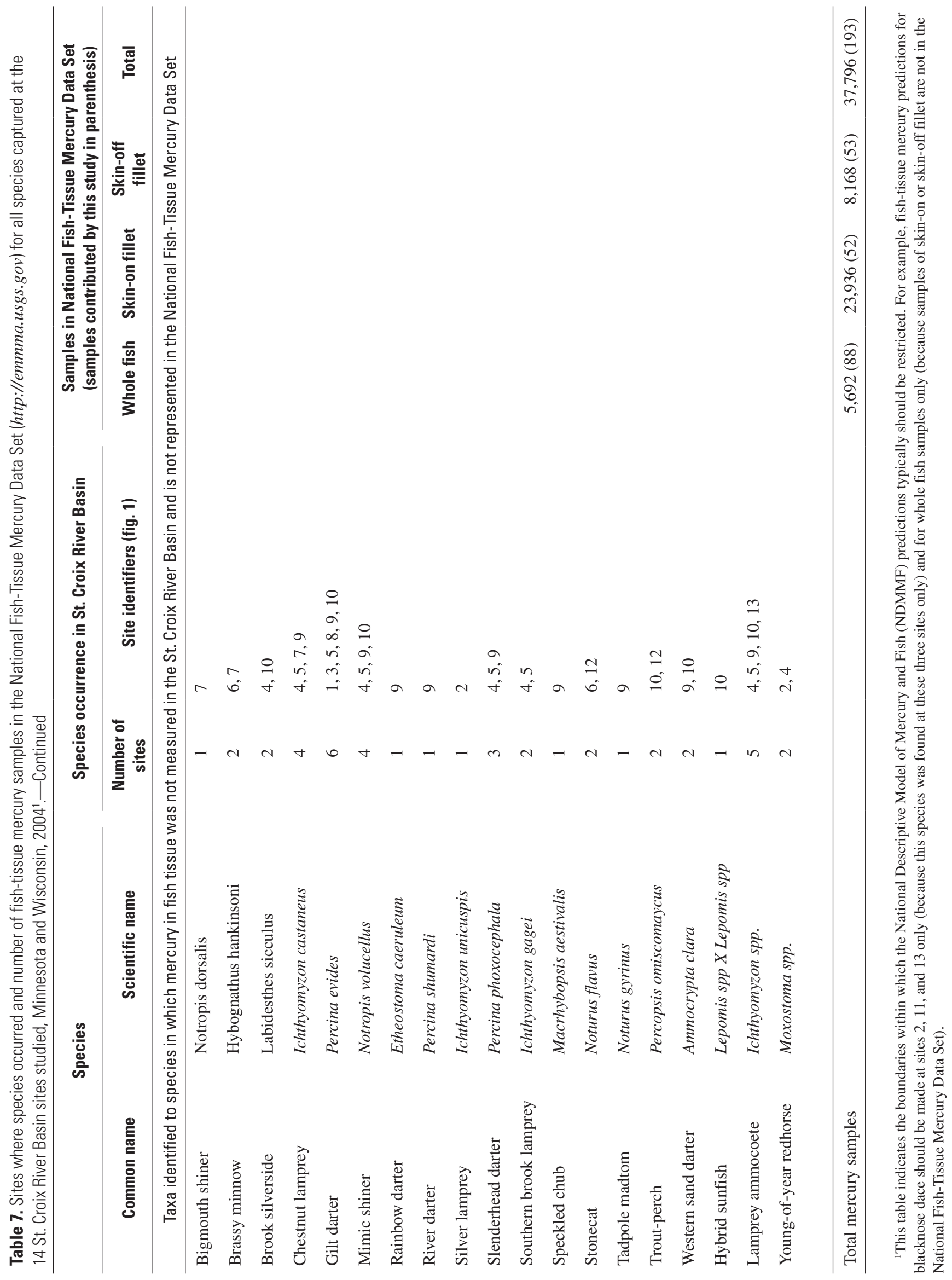




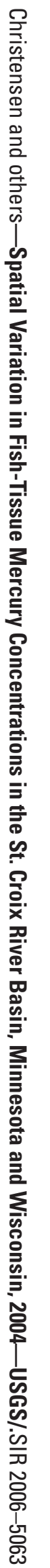

8 Printed on recycled paper 